A CERÂMICA CAPA DO CANGA: UMA NC INDÚSTRIA CERÂM

NA BACIA DO ALTO GUAPC MATO GROSSO, BR 


\section{A CERÂMICA CAPÃO DO CANGA: UMA NOVA INDÚSTRIA CERÂMICA NA BACIA DO ALTO GUAPORÉ, MATO GROSSO, BRASIL}




\title{
A CERÂMICA CAPÃO DO CANGA: UMA NOVA INDÚSTRIA CERÂMICA NA BACIA DO ALTO RIO GUAPORÉ, MATO GROSSO, BRASIL
}

\section{Resumo}

O alto rio Guaporé, por suas características e situação geográfica, foi uma região estratégica de convergência e/ou passagem de muitas populações indígenas pré-coloniais e etnohistóricas oriundas de regiões vizinhas, envolvendo desde possíveis grupos paleoíndios do Pleistoceno Superior a grupos pré-ceramistas arcaicos do Holoceno antigo e médio, ceramistas da era Cristã, bem como grupos etnohistóricos contemporâneos. Levantamentos arqueológicos efetuados pelo Projeto Fronteira Ocidental nas duas últimas décadas em um raio de $100 \mathrm{~km}$ na fronteira do estado do Mato Grosso com a Bolívia, levaram ao registro e estudo de 52 sítios arqueológicos distribuídos em cinco padrões de inserção dentro de três compartimentos geomorfológicos principais. Entre as ocupações ceramistas, cada qual concentrada nos compartimentos geomorfológicos ali existentes, foi possível reconhecer uma indústria cerâmica ainda inédita na literatura arqueológica concernente à área do alto rio Guaporé (cerâmica Capão do Canga), além de prováveis fenômenos de territorialidade e de existência de redes de trocas.

Palavras-chave: territorialidade, trocas, cerâmica, rio Guaporé.

\section{THE CAPÃO DO CANGA CERAMICS: A NEW CERAMIC INDUSTRY IN THE UPPER GUAPORÉ RIVER, MATO GROSSO, BRAZIL}

\begin{abstract}
The upper Guaporé river, by its characteristics and geographical location, was a strategic region of convergence and/or passage of many pre-colonial and ethno-historical indigenous peoples originating from neighboring regions , ranging from possible upper Pleistocene Paleoindians to pre-ceramic Archaic groups of early and middle Holocene, potters of the Christian era, as well as contemporary ethno-historical peoples. Archaeological surveys conducted by the Fronteira Ocidental Project in the last two decades in a radius of $100 \mathrm{~km}$ at the border of Mato Grosso and Bolivia, led to the record and study of 52 archaeological sites distributed comprising five settlement pattern, within three main geomorphologic compartments . Among the ceramic occupations, there is a previously unreported ceramic industry peculiar to the upper rio Guaporé archaeological area (Capão do Canga ceramics), including probable territoriality and the existence of networks exchanges.
\end{abstract}

Keywords: territoriality, trade, ceramics, Guaporé river. 


\section{LA CERÁMICA DEL CAPÓN DE CANGA: UNA NUEVA INDUSTRIA CERÁMICA EN EL ALTO RÍO GUAPORÉ, MATO GROSSO, BRASIL}

\section{Resumen}

El alto río Guaporé, por sus características y ubicación geográfica, ha sido una región estratégica de la convergencia y/o el paso de muchos pueblos indígenas pre-coloniales y etnohistóricos procedentes de las regiones vecinas, que van desde posibles grupos paleoindios del Pleistoceno Superior, a los grupos arcaicos ceramistas del Holoceno antiguo y medio, los alfareros de la era cristiana, así como los pueblos etnohistóricos contemporáneos. Los estudios arqueológicos llevados a cabo por el Proyecto de la Frontera Occidental en las últimas dos décadas en un radio de $100 \mathrm{~km}$ en la frontera de Mato Grosso y Bolivia, llevó a registrar y estudiar 52 sitios arqueológicos distribuidos en cinco patrones de de inserción en tres compartimentos geomorfológicos principales. Entre las ocupaciones de alfareros, cada uno centrado en los compartimientos geomorfológicos que existen allí, era posible reconocer una nueva industria cerámica relativa a la zona arqueológica de la parte superior del río Guaporé (cerámica Capón del Canga), incluyendo los fenómenos probables de la territorialidad y la existencia de redes intercambios.

Palabras-clave: territorialidad, comercio, cerámica, río Guaporé. 


\section{INTRODUÇÃO}

Esse artigo focaliza os resultados de pesquisa alcançados durante a fase exploratória de investigação de longo prazo desenvolvida no vale do alto rio Guaporé, estado do Mato Grosso e constitui uma das frentes do Projeto Fronteira Ocidental, em desenvolvimento pelo Governo do Estado do Mato Grosso na região guaporeana, tendo em vista a identificação, registro e preservação dos bens culturais para fins científicos e uso público. Os trabalhos desenvolvidos visaram à contribuição para o esclarecimento de um dos problemas de pesquisa na área em questão: a presença de uma nova indústria cerâmica, ainda inédita na literatura arqueológica para o ambiente de várzea do alto rio Guaporé, sendo esta denominada de cerâmica Capão do Canga, bem como a existência de um processo de territorialidade por parte dos grupos pré-coloniais a ela correlacionados, por meio da distribuição de seus respectivos sítios arqueológicos na paisagem, ou pela presença de exemplares desta cerâmica em outros sítios cerâmicos identificados, apontando também para a presença de antigas redes de trocas.

Por suas características e situação geográfica, o alto rio Guaporé contribuiu como uma região estratégica de convergência e/ou passagem de múltiplas populações indígenas pré-coloniais e etnohistóricas, oriundas de regiões vizinhas a esta porção peculiar do território sul-americano, entre as quais podemos citar o planalto central brasileiro, a Amazônia central e ocidental, a bacia do alto rio Paraguai, o pantanal e as terras baixas orientais da Bolívia.

\section{LOCALIZAÇÃO DA ÁREA DE PESQUISA}

A área de pesquisa englobou um raio de $100 \mathrm{~km}$, tendo como o seu epicentro o município de Vila Bela da Santíssima Trindade, localizado na mesorregião homogênea sudoeste mato-grossense, microrregião do alto rio Guaporé; na altura das coordenadas $15^{\circ} 00^{\prime} 28^{\prime \prime}$ e 59 $57^{\prime}$ 06”, a cerca de $521 \mathrm{~km}$ de Cuiabá. Considerando a calha do rio Guaporé como um dos eixos do levantamento arqueológico efetuado da região, podemos considerar os paralelos $14^{\circ}$ e $16^{\circ} \mathrm{S}$ como os limites da configuração de um espaço alto guaporeano alvo da pesquisa em questão (Erig Lima 2005, 2007, 2009, 2011) (Figura 1).

\section{RESULTADOS ALCANÇADOS}

O Projeto Fronteira Ocidental permitiu o levantamento de 52 sítios arqueológicos (17 multicomponenciais, contendo, além de vestígios pré-coloniais, peças históricas dos séculos XVIII ao XX), além de 32 ocorrências líticas ou cerâmicas (Figura 2). A pesquisa aqui relatada incluiu a definição de uma tipologia desses sítios, de seus padrões de assentamento e prováveis modelos adaptativos nos compartimentos morfológicos da área em questão tendo sido identificada uma indústria ceramista ainda inédita na literatura arqueológica brasileira: a cerâmica Capão do Canga. Utiliza-se aqui a definição de sistema regional de povoamento proposta por Morais (2000:9): "A coordenação entre sítios ou conjuntos de sítios pautada por relações sociais, econômicas e culturais (considerando sua contemporaneidade, similaridade ou complementaridade). 


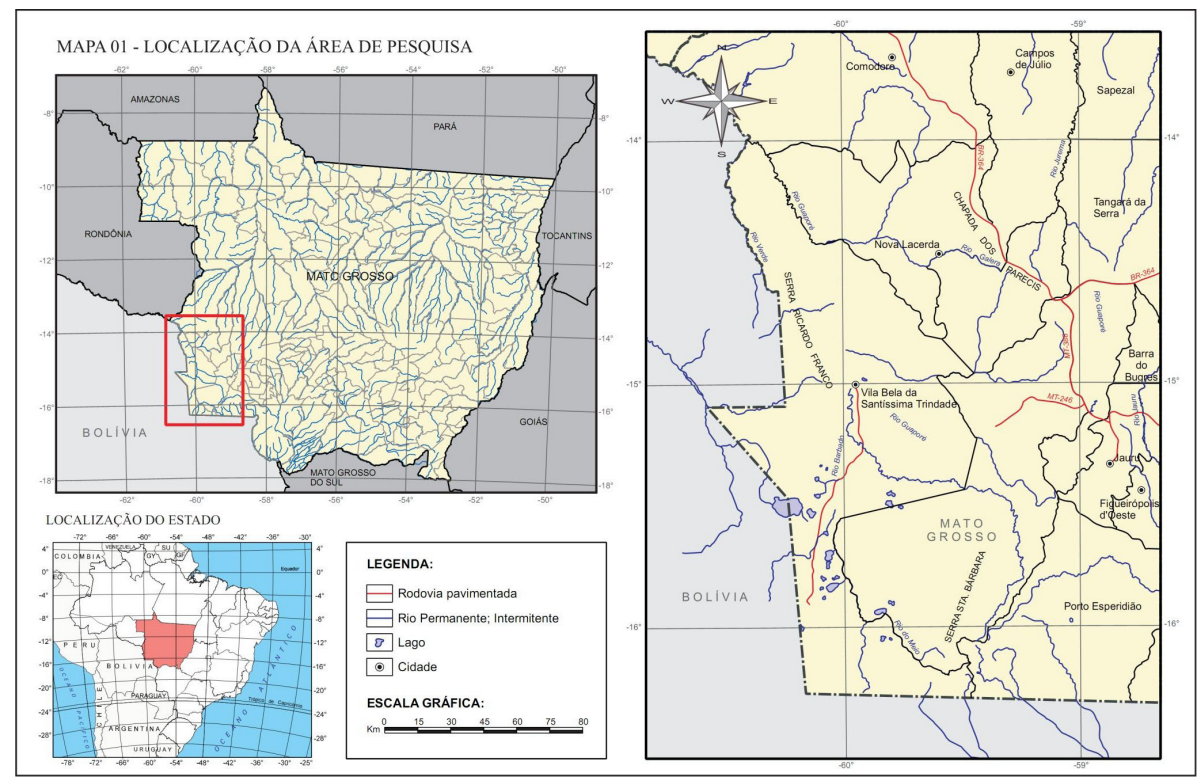

Figura 1 - Localização da área de pesquisa: bacia do alto rio Guaporé

Os resultados revelaram a existência de três períodos principais de ocupação pré-colonial: o primeiro por caçadorescoletores do Holoceno Médio, o segundo por grupos ceramistas e o terceiro por grupos etnohistóricos. Os vestígios se distribuíram de acordo com os principais compartimentos geomorfológicos existentes na área, sendo 30 sítios identificados na planicie e pantanal do alto/médio Guaporé, três sítios e duas ocorrências no planalto residual alto Guaporé e 19 sítios e 30 ocorrências na depressão do Guaporé. Foram coletados 15.904 artefatos cerâmicos (1.226 analisados) e 1.984 líticos (179 analisados), oriundos de coleta amostral seletiva e de resgate arqueológico em um ou mais sítios. Dezessete (17) sítios são multicomponenciais, envolvendo um horizonte de ocupação histórico luso-africano.

Anteriormente a este trabalho, havia carência de publicações ou de levanta- mentos regionais arqueológicos referentes à área. Conhecia-se a dissertação de Eurico Th. Miller (1983) para o alto-médio rio Guaporé; além de diversos sítios e fases arqueológicas levantados por ele na década de 1970, hoje disponíveis no cadastro do CNSA-IPHAN. Embora associados à região em estudo, não se dispõe de publicações com maiores detalhes envolvendo dados de análises e descrições lito-cerâmicas, sendo o sítio Abrigo do Sol abordado em algumas publicações (Puttkamer 1979; Miller 1987, 2000). Quanto às fases ceramistas, há breves descrições ou datações disponíveis. Grande parte deste material encontra-se depositado na reserva técnica do Museu de Taquara/ RS, à espera de curadoria e análise (Wüst 2001: 277).

Os trabalhos mais recentes envolveram um levantamento de sítios na porção ocidental do rio Barbado por Miguel Gleiser e Oldemar Blasi (SPVS 1997 
a, b), igualmente sem detalhes quanto à descrição dos sítios ou de seus materiais. Por outro lado, trabalhos mais completos e detalhados foram desenvolvidos com os projetos de arqueologia de resgate das UHEs Guaporé (Wüst 2001; Fogaça \& Sampaio 2003).

A distribuição das indústrias cerâmicas de acordo com os principais compartimentos geomorfológicos da região, de seus elementos diagnósticos decorativos e formas de vasilhames, principalmente as da cerâmica Capão do Canga, permitiu reconhecer a existência de redes de trocas e de interdependência tecnológicas entre as populações précoloniais da área, bem como fenômenos de territorialidade entre si.

Diante deste quadro complexo, até o momento foi possível identificar as se- guintes ocupações cronológico-culturais: caçadores-coletores do Holoceno Médio (9/8-2 mil AP), Tradição Una (500 AC-1200 AD), Indústrias Ceramistas da Micro-Bacia do Córrego Banhado/ Cerâmica Córrego Banhado (500-1400 AD), Cerâmica Capão do Canga (8001300 AD), Tradição Uru (800-1700 AD), Tradição Tupiguarani (1300/1400-1700 $\mathrm{AD})$, e ocupações etnohistóricas tardias representadas por prováveis grupos Cabixi ou Nambiquara (Sécs. XIX e XX).

\section{IDENTIFICANDO A CERÂMICA CAPÃO DO CANGA}

A indústria cerâmica denominada como Cerâmica Capão do Canga foi pela primeira vez observada no sítio arqueológico homônimo, situado na área da Fazenda Lagoa do Encanto,

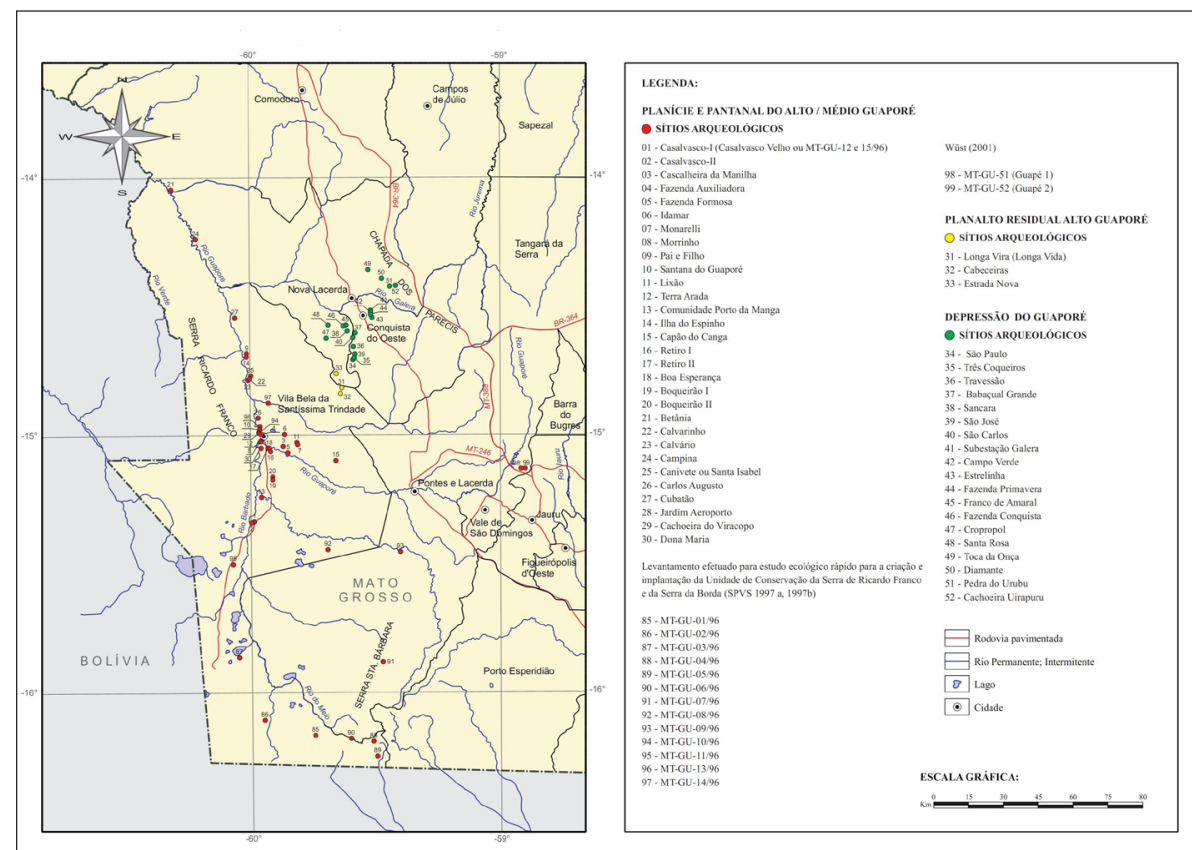

Figura 2 - Localização dos sítios arqueológicos levantados na área pesquisada 
município de Vila Bela da Santíssima Trindade, durante o diagnóstico da Nova Alça de Acesso, na cidade de Vila Bela (Zanettini Arqueologia 2002). A área do entorno imediato ao sítio é rica em depósitos lateríticos, muito utilizados para aterros e pavimentações na região, e há anos era explorada como área de empréstimo em obras fortuitas, ou mesmo pelo DNER quando da abertura da rodovia BR-174.

Um ponto que chama a atenção nesta cerâmica é a presença de decoração pela técnica plástica incisa ou pintada (vermelho), conferindo um belo motivo de linhas entrecruzadas, cuidadosamente executadas em algumas peças. Com o primeiro levantamento regional efetuado pelo Projeto Fronteira Ocidental essa cerâmica começou a se repetir em outros sítios da região (Zanettini Arqueologia 2004 a), porém, não se associava a qualquer afiliação cronológico-cultural descrita para a bibliografia disponível para a macro-região de entorno. Cabia então um estudo mais profundo, pois uma indústria ceramista pré-colonial, até então inédita para o alto rio Guaporé, começava a se configurar na medida em que os achados prosseguiam ou algumas peças cerâmicas eram doadas ao Museu Histórico e Arqueológico de Vila Bela (Museu Joaquim Marcelo Profeta da Cruz). Assim, o material cerâmico do sítio Capão do Canga tornou-se a coleção de referência para os aspectos gerais desta indústria, visto contar com um maior número de peças e variabilidade de técnicas decorativas. Antes das datações de termolumi- nescência (TL) efetuadas ${ }^{1}$ para essa cerâmica, pairava uma série de dúvidas quanto a sua real origem, visto a região de Vila Bela apresentar uma ocupação luso-africana ali presente desde o século XVIII, além de grande miscigenação de grupos etnohistóricos indígenas, provocada pelo processo das missões espanholas na margem oposta do Guaporé (Erig Lima 2005). Sua origem seria ibero-africana ou indígena? Se indígena, seria pré-colonial ou etnohistórica? Seria o sítio Capão do Canga uma aldeia pré-colonial ou um aldeamento indígena colonial, ou quiçá um quilombo?

A presença desta cerâmica em alguns sítios históricos no entorno de Vila Bela (Dona Maria, por exemplo) apontava para a hipótese de uma produção artesanal local de origem luso-africana, considerando que ocorria de modo associado com materiais de origem europeia (vidro, faiança, faiança-fina, metais) ou cerâmicas históricas de produção local, com técnica de construção torneada ou acordelada: panelas com apêndices ou alças e moringas, às vezes escovadas e, em geral, com uma pasta argilosa muito fina e dura. Pesquisas efetuadas nas ruínas do arraial de São Francisco Xavier da Chapada revelaram, durante a etapa de limpeza e anastilose de uma pequena estrutura construtiva (SH-01), fragmentos cerâmicos com um padrão decorativo semelhante de linhas incisas entrecruzadas (Zanettini Arqueologia 2004 b: Prancha 46).

A hipótese de uma origem etnohistórica foi especulada a partir de alguns fragmentos cerâmicos incisos com padrão entrecruzado, os quais foram 
observados entre alguns alicerces das ruínas do sítio histórico de Casalvasco Velho (ou Casalvasco-I), localizado na margem direita do rio Barbado. Um pormenor interessante é que para a fronteira ocidental do vale do Guaporé, Meireles (1989: 57, 59, 193), ao mencionar o mapa etnográfico de Montfort e Rivet, indica nesta área a presença do grupo indígena Saraveka, ${ }^{2}$ durante o século XVIII; após a saída dos jesuítas, grande parte desses indígenas concentrados nas missões teria migrado para Casalvasco, havendo também uma imigração para essa localidade de 479 índios Chiquitos, em 1819. Tornava-se tentador considerar a contribuição do elemento indígena ali fixado em sua produção, porém, remetendo-nos a um horizonte cronológico histórico.

A hipótese de uma origem pré-colonial contou com uma série de dados comparativos. Um artigo escrito por Puttkamer (1979), para a revista norteamericana National Geographic, dizia respeito às pesquisas desenvolvidas pelo arqueólogo Eurico Th. Miller no sítio Abrigo do Sol, localizado no rio Galera. Entre as ilustrações de alguns fragmentos cerâmicos, contava-se com um fragmento cuja decoração incisa (motivos de linhas entrecruzadas) era semelhante à existente na coleção do sítio Capão do Canga. Porém, os níveis cerâmicos superiores do abrigo estariam associados à Fase Aguapé, que possui uma data de 1945 anos AP (AD 5), sendo esta também registrada em 14 sítios a céu aberto e cinco em abrigos sob rocha ${ }^{3}$. Segundo informação pessoal de E. Th. Miller (2003), esta é a ocorrência cerâmica mais comum na região, e se encontra prestes a ser considerada como uma tradição, sendo também encontrada das nascentes do rio Juruena até a Chapada dos Parecis no lado rondoniense.

Em alguns fragmentos incisos da fase Corumbiara (900-1700 AD), estudados no alto-médio rio Guaporé por Miller (1983, estampa 7: m, u), observa-se um padrão de linhas entrecruzadas em espaços regulares, classificado como o tipo decorativo Rolim Inciso. Alguns fragmentos com decoração pintada procedentes do sítio MT-PO-02, afiliado à Tradição Descavaldos, apresentam um padrão decorativo de linhas entrecruzadas (Migliacio 2006).

O resgate dos sítios Guapé 1 e 2 (Alto Guaporé), na área das Obras da Usina Hidrelétrica Guaporé (Wüst 2001), revelaram uma cerâmica também ricamente decorada com motivos incisos. No entanto, diferem daqueles presentes no Capão do Canga; apresentam zonados na borda, representando linhas entrecruzadas, às vezes associadas a animais estilizados (batráquios). Esta cerâmica foi denominada de Cerâmica Guapé e encontra-se cronologicamente situada entre 1.330 a 1.660 AD. Vale ressaltar que as incisões verificadas nesta cerâmica foram efetuadas tanto antes da queima como após a queima, enquanto na cerâmica do sítio Capão do Canga, as incisões foram realizadas anteriormente à queima.

Dados etnográficos apontaram para a hipótese de uma origem pré-colonial: o motivo de linhas entrecruzadas era um 
padrão de pintura corporal comum entre os índios Huanyan, conforme registros efetuados por Erland Nordenskiöld (2001: 261, 262), no médio rio Guaporé boliviano durante o início do século XX. Com o genipapo, produzia-se nos antebraços e panturrilhas o motivo de linhas entrecruzadas, o qual era denominado de "chiquin", uma espécie de peixe.

Trabalhos de etnoarqueologia desenvolvidos por Moi et al. (2009: 219, foto 6) entre os grupos Haliti-Paresi e Enawene Nawe das bacias dos rios do Sangue e Juruena, Mato Grosso, apontam também à existência deste motivo entrecruzado em algumas gravuras rupestres identificadas no teto do abrigo Veia Peia.

A partir de janeiro de 2005, com o resgate definitivo do Sítio Capão do Canga, as primeiras análises cerâmicas foram encabeçadas pelas arqueólogas Camila Azevedo Moraes e Valeria Cristina Ferreira e Silva. Além de uma melhor caracterização dos padrões decorativos, os primeiros desenhos de bordas efetuados indicaram vasilhames pequenos a médios, globulares e de contorno infletido fechado - destinados à estocagem (Zanettini Arqueologia 2002).

As ações de resgate vieram a indicar que o sítio em questão seria um típico assentamento indígena pré-colonial. Além de farto material cerâmico, havia peças líticas (quebra-côco, lâmina de machado), bem como a ausência de material histórico em quantidade que pudesse atestar uma ocupação de período histórico. Todavia, durante as análises foi identificado um fragmento de cerâmica histórica intrusiva, certa- mente oriundo ${ }^{4}$ de uma reocupação posterior.

Durante os trabalhos, um tratorista prestou uma interessante informação à equipe: por volta de 1999, durante as atividades de lavra do cascalho laterítico nesse sítio, o corte do maquinário no terreno revelou a presença de urnas cerâmicas contendo ossos humanos, peças líticas e contas de colar, cujo material aparentava tratar-se de resina, osso ou semente deteriorada, pois, segundo o relato, "se desmanchariam ao toque dos dedos". Nesse sentido, o sítio em estudo poderia ter uma função especializada além da habitacional, entre as quais se destacaria a ritual-funerária.

Com o prosseguimento de outros trabalhos, principalmente na área de Depressão do Guaporé (Zanettini Arqueologia 2006, 2007), a descoberta de fragmentos de cerâmica Capão do Canga intrusiva em sítios de cerâmica Córrego Banhado (apresenta correlações às Fases Corumbiara e Pimenteira: 800-1700 AD), bem como a presença de fragmentos de cerâmica Uru, intrusivas em sítios de ocupação Capão do Canga, reforçaram ainda mais a hipótese de uma contemporaneidade pré-colonial, o que foi definitivamente atestado por análises de termoluminescência.

Apesar desta indústria cerâmica e seu sítio associado contarem com apenas duas datações $(750 \pm 80 \text { e } 1.000 \pm 160 \mathrm{AP})^{5}$ de TL, foi possível situar um horizonte de ocupação de 800-1300 AD, não pairando mais dúvidas quanto a ser uma ocupação cerâmica pré-colonial. 


\section{ASPECTOS GERAIS DA CERÂMICA CAPÃO DO CANGA}

É importante salientar que os aspectos gerais aqui descritos para essa cerâmica, conforme já explanado, tem como coleção de referência o material procedente do sítio Capão do Canga, sendo enfatizados os pormenores principais e congruentes com as demais coleções cerâmicas afiliadas a esta ocupação pré-colonial. Nas análises efetuadas em cada sítio, de modo detalhado, foi possível observar uma grande variabilidade de tratamentos de pastas, combinações de antiplásticos, tipos de queima, além de outros aspectos.

Há um uso predominante de pastas plásticas a muito plásticas, em meio a uma matriz argilosa. $\mathrm{O}$ antiplástico predominante é a combinação do quartzo (predominante), hematita (comum), mica (pouco) e feldspato (raro) com o cauixí, podendo estar associado com o caco moído e/ou bolota de argila. O cariapé pode ocorrer em baixa porcentagem. A técnica construtiva é o acordelado, sendo as bases modeladas, com espessura dos vasilhames de 2 a $25 \mathrm{~mm}$, e predomínio de $7 \mathrm{~mm}$. As queimas predominantes são oxidantes, com núcleos de seção uniforme variando do laranja tijolo ao amarelo.

Entre os tratamentos de superfície externa e interna, o mais comum é o de alisamento, em menores porcentuais há o banho e o engobo vermelhos, bem como o enegrecimento e a brunidura. Raramente há o polimento e o engobo creme. Todos esses acabamentos podem ocorrer de forma isolada ou combinada entre si.
A decoração predominante é a plástica incisa, seguida pela pintada. As demais decorações plásticas como o acordelado, corrugado, escovado, estocado, ponteado, raspado, ungulado ou digitado (Figuras 8 a 14) são quase raras, principalmente as duas últimas, cujas presenças nos vasilhames tendem a ocorrer mais como acidentes durante o processo de confecção, do que como elementos decorativos pré-concebidos.

Provavelmente o instrumento de incisão empregado seria um espinho de palmeira de tucum (Astrocarium spp.), cabendo ao artesão a escolha da largura da linha a ser incisa: para um trabalho mais tênue bastaria utilizar a extremidade aguçada e, para as incisões mais grossas, bastaria romper o espinho utilizando sua seção da porção mediana ou da base, formando assim uma extremidade rombuda.

Quanto à decoração pintada, essa ocorre exclusivamente na cor vermelha, de modo que os pigmentos seriam obtidos a partir da maceração de óxidos férricos, presentes nos depósitos lateríticos ou de "pedra-canga" bastante abundantes nas áreas alagadiças da região em estudo. $\mathrm{O}$ instrumento utilizado para produzir a pintura poderia ser algum graveto ou haste de taquara, com uma extremidade entalhada de forma espatulada, no caso de faixas largas, ou, de ponta triangular aguçada, no caso de faixas mais finas.

As decorações eram aplicadas sobre a face externa dos vasilhames, cujo principal tratamento de superfície era o de alisamento (Figura 3), com poucos exemplos apresentando enegrecimen- 
to, e, raros apresentando brunidura, polimento, engobo creme, engobo ou banho vermelhos: nos dois últimos exemplos, no caso de pintura, utilizava-se um pigmento de tonalidade mais forte que o de acabamento de superfície.

Os motivos ocorrem preferencialmente no bojo dos vasilhames, bem como em suas bordas, pouco abaixo da linha do lábio. Às vezes a decoração, fosse incisa ou pintada, poderia atingir a base do vasilhame durante seu acabamento. Foi possível definir seis padrões principais de motivos decorativos (Figuras 3 e 4): (1) Linha unitária simples; (2) Linhas compostas horizontais; (3) Linhas compostas verticais; (4) Linhas compostas diagonais: inclinadas à direita ou esquerda; (5) Linhas compostas entrecruzadas: é o padrão mais recorrente, subdivide-se em regular ("escama de peixe"), aleatório, regular e horizontal, regular e vertical, reticulado ("jogo da velha") com diagonal à esquerda ou direita; (6) Vestígios: decoração intemperizada impossibilitando identificação do padrão.

A partir de reconstituições de perfis de bordas, há um predomínio de formas extrovertidas sendo essas seguidas pelas diretas (Figuras 6 e 7). Entre as primeiras, o diâmetro de seus vasilhames oscila de 6 a $26 \mathrm{~cm}$, sendo mais frequente entre 10 e $12 \mathrm{~cm}$; enquanto nas segundas, de 5 a $36 \mathrm{~cm}$, sendo mais frequente entre 10 e $12 \mathrm{~cm}$. Ambas as formas apresentam inclinações de bordas dos tipos inclinada interna, inclinada externa e vertical, sendo os lábios dos tipos arredondados, planos e apontados. De um modo geral os vasilhames apresentam formas fechadas.

Quanto aos tipos de bases, ocorrem as de morfologia plana de faces externas rugosas ou com decoração plástica digitada; há também as de morfologia convexa com faces externas rugosas ${ }^{6}$ a alisadas, bem como as anelares.

Entre as principais formas ${ }^{7}$ e suas respectivas funções, temos:

CG 1 a $1 A$ - Tigelas fundas de formato geral semiesférico ou globular, função: serviço e consumo de alimentos ou bebidas.

CG 2 - Tigelas predominantemente

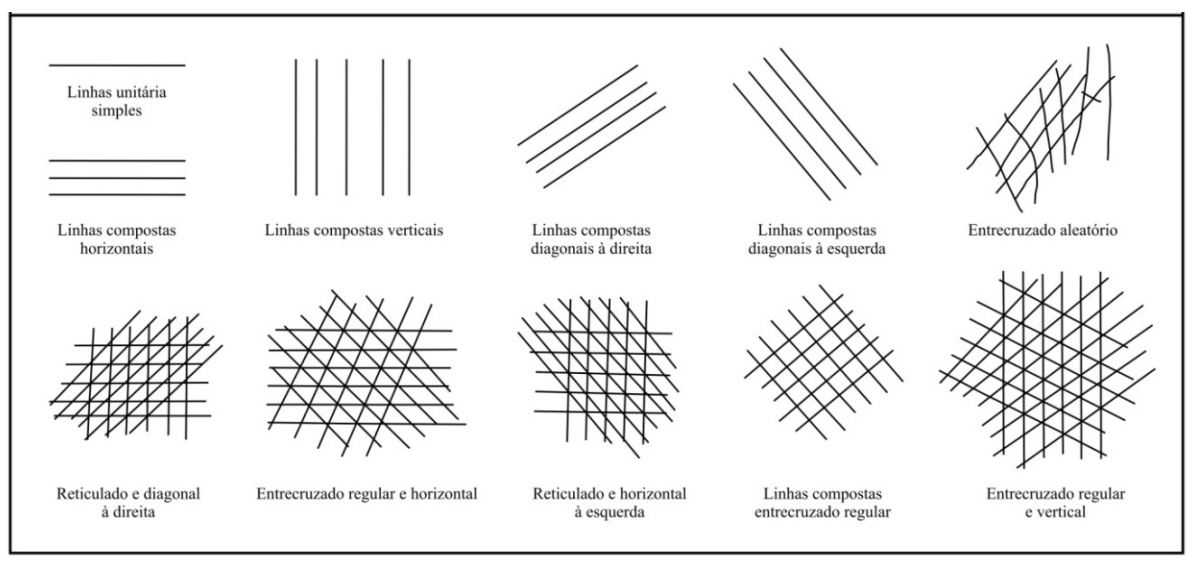

Figura 3 - Padrões decorativos nos motivos plásticos incisos da Cerâmica Capão do Canga. 


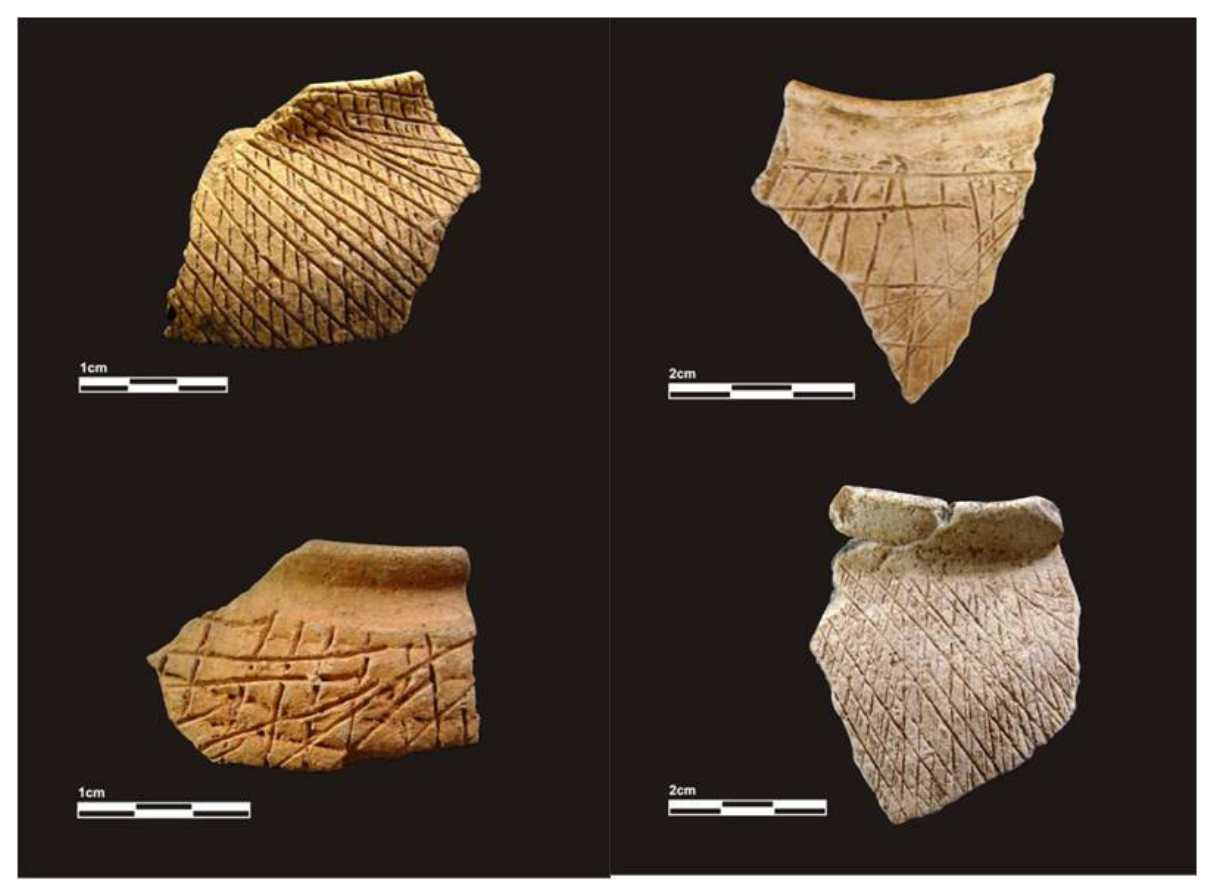

Figura 4 - Exemplos de fragmentos de Cerâmica Capão do Canga com decoração plástica incisa.

rasas (algumas de profundidades medianas), função: serviço e consumo de alimentos ou bebidas, ou mesmo ritual a lúdica no caso de exemplos menores.

CG 3 a $3 A$ - Vasilhames globulares de boca circular constrita de contorno simples a composto. Função: armazenagem d'água ou bebidas alcoólicas, ou mesmo alimentos.

CG 4 - Vasilhames de boca circular ampliada, contorno infletido e bojo globular, função: preparo e cocção de alimentos ou bebidas (peças de maior diâmetro) ou armazenagem, ritual ou lúdicas (peças de menor diâmetro).

CG 5 - Vasilhames globulares de boca circular constrita e contorno simples, função: armazenagem d'água ou bebidas alcoólicas, ou mesmo alimentos.
Chama a atenção as formas supracitadas com função de serviço, consumo ou armazenagem, que também poderiam ter uma reutilização de uso ao fogo, ao julgar pela presença de fuligem ou depósitos de carbono em alguns fragmentos estudados. Considerando as formas CG 3, 3A e 5 em termos de eficiência de resfriamento de água e outros líquidos, essas poderiam ter sua "vida útil" abreviada por obstrução dos poros da pasta cerâmica, o que reduziria a permeabilidade do vasilhame, importante fator no resfriamento. Esse processo se daria pela migração iônica de sais na argila para a superfície de evaporação, os quais se precipitariam na forma de sais insolúveis (Skibo et al. 1989: 130). Assim, posteriormente, poderiam ser utilizados em funções de cocção ou mesmo fins funerários (ver figura 5). 
A partir de fragmentos cerâmicos reciclados $^{8}$, poderiam ocorrer pesos de fusos, ao julgar por vestígios de perfurações, ou, pesos de redes, ao julgar por sulcos entalhados em todo o entorno do fragmento para amarração de um cordão, nesse caso, não se descartando também uma função lúdica.

\section{DISCUSSÃO DOS DADOS}

Entre as principais ocupações ceramistas na área, contamos com aquelas associadas à cerâmica Capão do Canga e às indústrias cerâmicas da micro-ba- cia do Córrego Banhado (ou simplesmente cerâmica Córrego Banhado) cujos sítios predominam, respectivamente, nos compartimentos da planície e pantanal do alto/ médio rio Guaporé e na depressão do Guaporé; de modo intrusivo a essas cerâmicas encontraremos alguns fragmentos das Tradições Uru e Tupiguarani, a segunda observada em sítios multicomponenciais históricos da várzea do rio Guaporé. Raros vestígios da Tradição Una foram também reconhecidos em um sítio multicomponencial histórico na várzea do rio Guaporé, e em uma ocorrência na depressão do Guaporé.

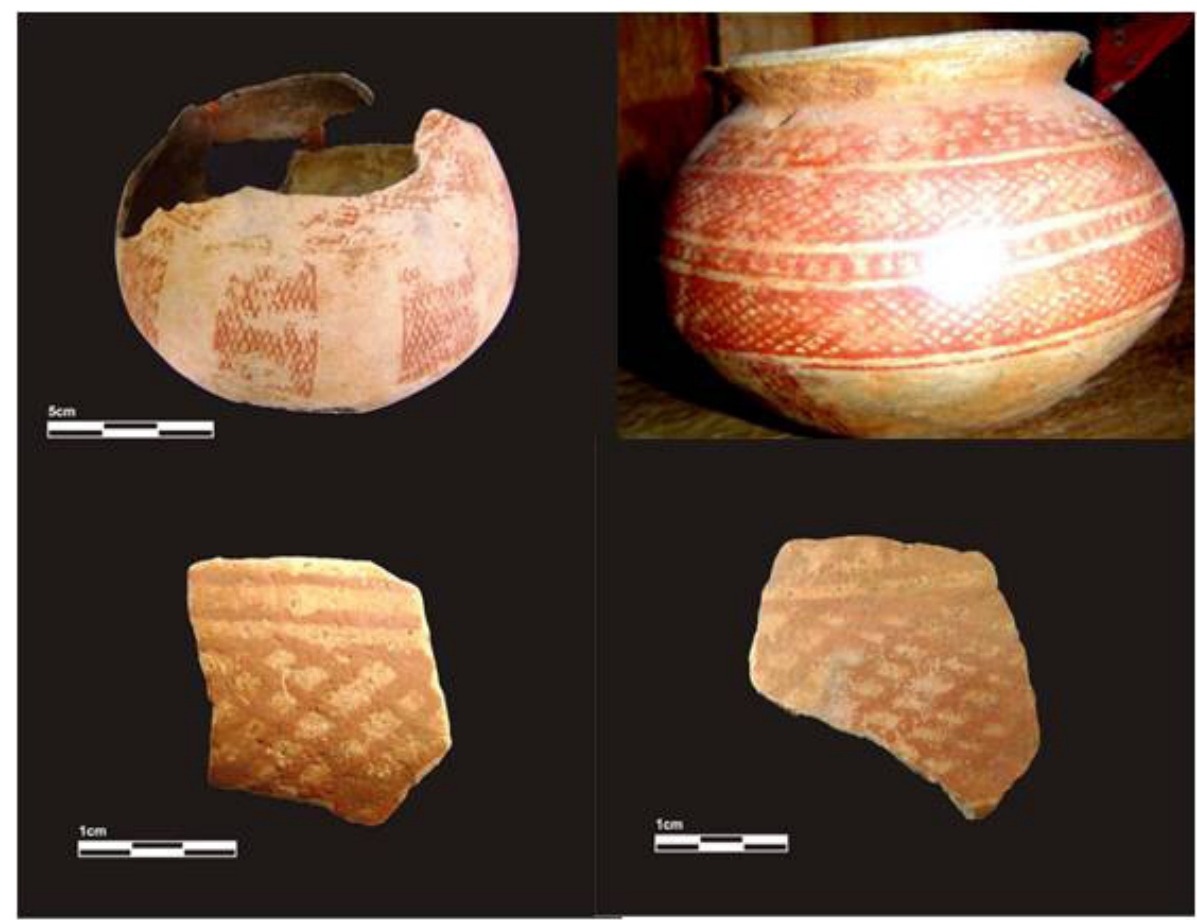

Figura 5 - Vasilhames globulares e fragmentos de Cerâmica Capão do Canga com decoração pintada no motivo de faixas entrecruzadas. O vasilhame acima e à esquerda (doação 10, Museu Histórico e Arqueológico de Vila Bela) conteria restos ósseos de indivíduo infantil, tendo sido encontrado $60 \mathrm{~km}$ ao norte da cidade de Vila Bela da Ssa. Trindade. $\mathrm{O}$ vasilhame acima e à direita foi depositado como oferenda funerária em uma urna da indústria cerâmica Córrego Banhado. 
Erig Lima, L. F.

CG 1
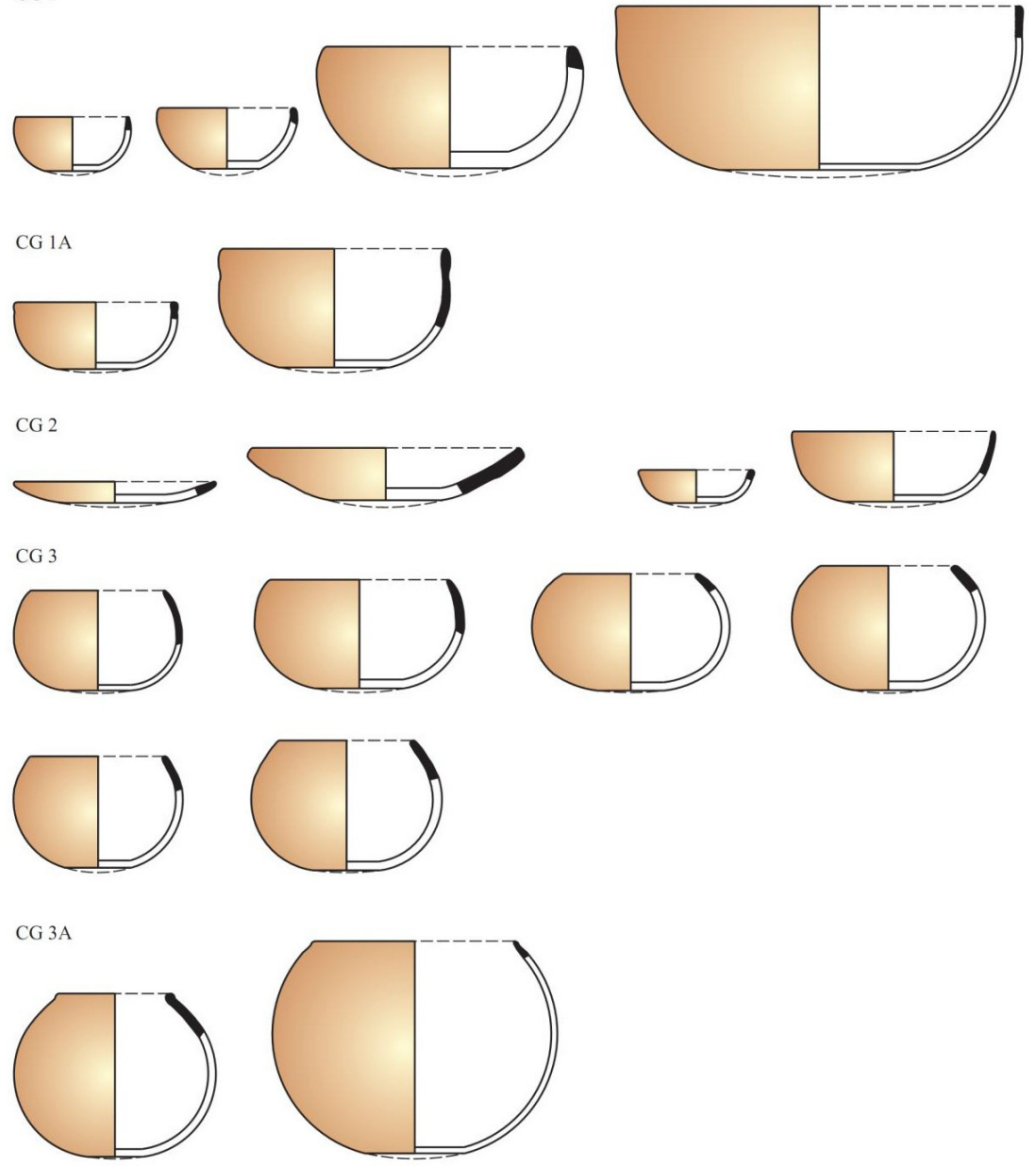

CG 4
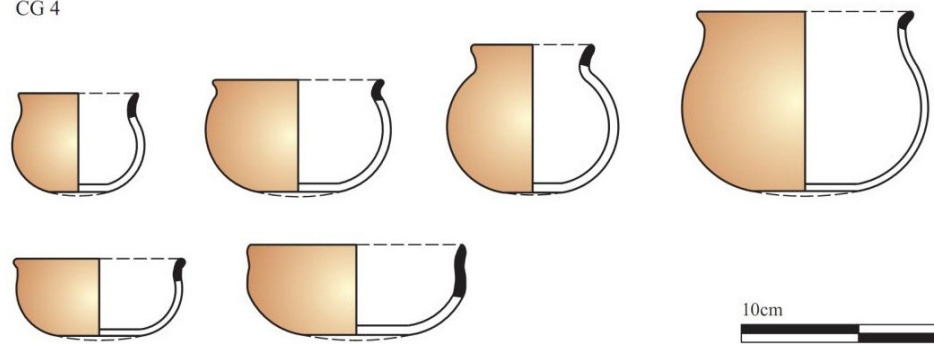

$10 \mathrm{~cm}$

Figura 6-Formas de vasilhames reconstituídos da Cerâmica Capão do Canga 


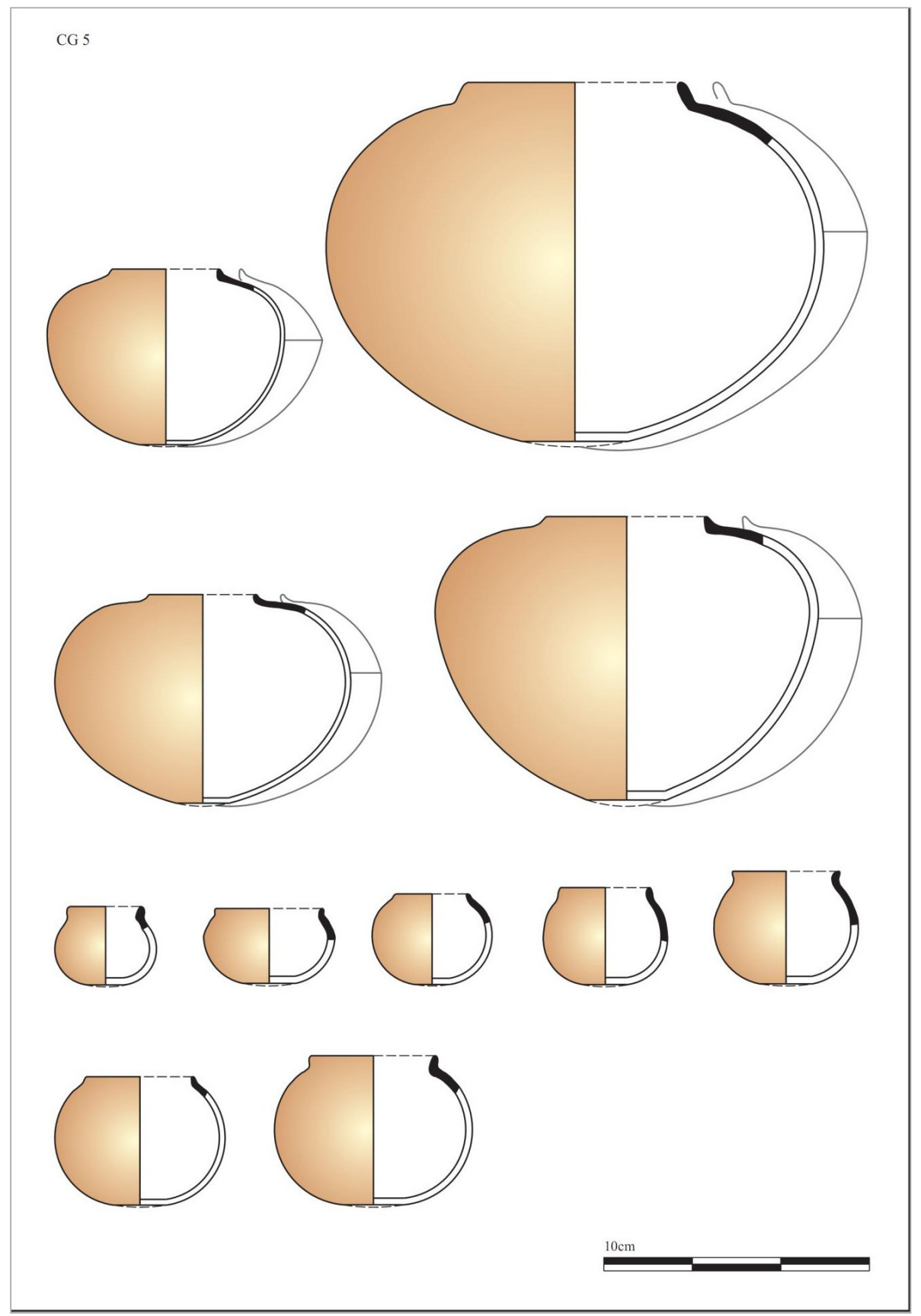

Figura 7 - Formas de vasilhames reconstituídos da Cerâmica Capão do Canga 
Procurando obedecer a uma ordem cronológica baseada em literatura pertinente e nas datações de termoluminescência efetuadas para alguns sítios estudados, temos um intervalo geral de ocupação ceramista situado entre 500 e 1400 AD. Suas origens e expansões certamente teriam sido beneficiadas por uma maior multiplicidade de recursos de flora e fauna, com o advento das atuais condições de temperatura e umidade por volta de 2000 AP, bem como por um auge de elevação dessas condições entre 900 e 950 AD (Miller 1983: 254-255; 283-285).

Seguindo este raciocínio, as manifestações ceramistas mais antigas até agora identificadas no vale do rio Guaporé, depois das ocupações ceramistas dos sambaquis fluviais da fase Bacabal, são representadas pelas fases Poaia e Aguapé, a primeira com datação de 2500 a 1945 \pm 55 anos AP (SI-3744), subjacente à segunda, a qual possui uma datação de 1.945 anos AP (AD 5) (Miller 2000: 336; Wüst 2001: 271). Seus sítios tendem a ocorrer em abrigos sob rocha nas cuestas da Chapada dos Parecis ou em sítios a céu aberto.

Quanto à Tradição Una, seus prováveis vestígios foram reconhecidos a partir de raros fragmentos cerâmicos de pasta de cor preta temperada com cariapé, procedentes do sítio Ilha do Espinho, localizado em uma planície de baía no compartimento da planície e pantanal do alto/ médio rio Guaporé, no subcompartimento das Planícies Fluviais Amplas (A1), bem como pela Ocorrência-10 (OC-10), localizada no compartimento da depressão do Guaporé.
Em princípio, com a presença do tempero de cariapé na pasta, aventou-se também a possibilidade de uma afiliação à fase Poaia, mas a ausência de outros traços diagnósticos (formas de vasilhames e incisões plásticas) e a relativa distância com as cuestas da Chapada dos Parecis não permitiram uma associação segura.

Se confirmada futuramente a presença da Tradição Una nos contextos estudados, isto seria um dado de grande importância no que tange ao conhecimento de sua expansão além das fronteiras dos chapadões do Brasil Central. No caso de uma datação bem recuada, poderíamos considerar como uma das primeiras ocupações ceramistas a se instalarem na área do alto rio Guaporé, explorando e disputando os recursos ecológicos da região ao lado das fases Poaia e Aguapé.

No caso das datações vierem a ser relativamente tardias, é possível imaginar que a presença desta ocupação ceramista poderia ter se dado na forma de pequenos grupos sob constante deslocamento, buscando áreas isoladas em cabeceiras de córregos contributários aos principais rios da região, ou mesmo em baías e planícies fluviais ainda não tomadas pelas grandes ocupações ceramistas predominantes na região.

Posteriormente, entre 500-1400 AD a região foi ocupada por um grupo ceramista produtor da cerâmica Córrego Banhado, representada de modo predominante por sítios registrados no compartimento geomorfológico da depressão do Guaporé e alguns sítios no compartimento da planície e pantanal do alto/médio rio Guaporé. Sua 


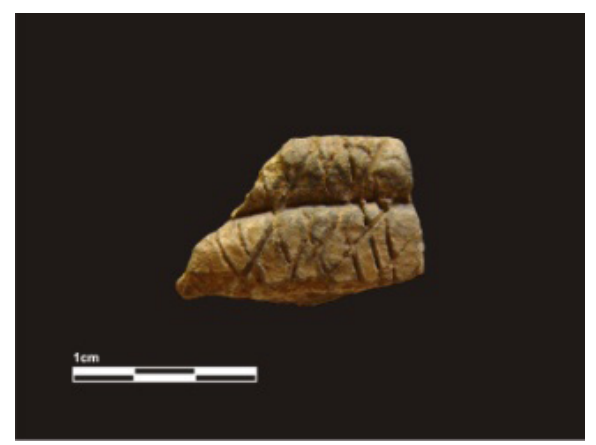

Figura 8 - Decoração plástica incisa com motivos de linhas compostas diagonais associadas à técnica decorativa acordelada, essa resultante do processo construtivo dos vasilhames.

cerâmica apresenta um tempero predominantemente mineral, com grande porcentual de areias quartzosas; a mica (muscovita) pode se destacar na coleção cerâmica de alguns sítios; antiplásticos orgânicos como o cariapé e o cauixí, tendem a ocorrer em baixa porcentagem. Há uma grande variabilidade de formas de vasilhames: 21 no total.

Algumas características observadas entre alguns perfis de bordas de vasilhames e elementos decorativos, principalmente os motivos incisos e ponteados ${ }^{9}$ entre as decorações plásticas, permitem uma correlação com as Fases Corumbiara e Pimenteira (900-1700 AD), definidas para o alto-médio rio Guaporé por Miller (1983: 275), ambas as quais poderiam ser comumente englobadas à Fase Paraguá e ao Complexo Arqueológico de Los Gomales da Bolívia, visto haver algumas similaridades decorativas entre suas cerâmicas. Curiosamente foram identificados pesos de fusos modelados de forma estrelada (4 a 6 pontas) no mesmo estilo de exemplos encontrados na área cultural de Los

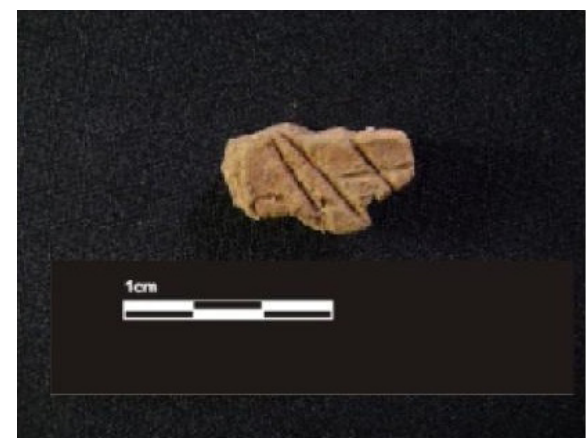

Figura 9 - Decoração plástica incisa com motivos de linhas compostas entrecruzadas associadas a um motivo plástico ungulado.

Mojos (rio Beni, Bolívia), além de raros fragmentos de armações de maças líticas (Itaiçás) com formas circulares a cruciformes com perfuração central bicônica, atestando uma origem andina/subandina: esses elementos permitiram avaliar a existência de redes de intercâmbio com regiões distantes.

Ligações culturais entre as fases Corumbiara e Pimenteiras com a área de Los Mojos-Chiquitos já eram propostas por Miller (1983: 264), visto a recorrência de faces de jaguares nos motivos incisos das cerâmicas estudadas no alto-médio rio Guaporé, o que poderia remeter ao culto do jaguar, traço mítico e sócio-religioso característico dos Mojo (Métraux 1948). Desse modo, não seria estranho se essas ligações se direcionassem à montante do Guaporé, trazendo consigo outros elementos culturais do território boliviano.

Outro ponto interessante que envolve a cerâmica Córrego Banhado é a presença de uma estrutura de vala defensiva descrita para o sítio Fazenda Auxiliadora, localizado em um terraço 


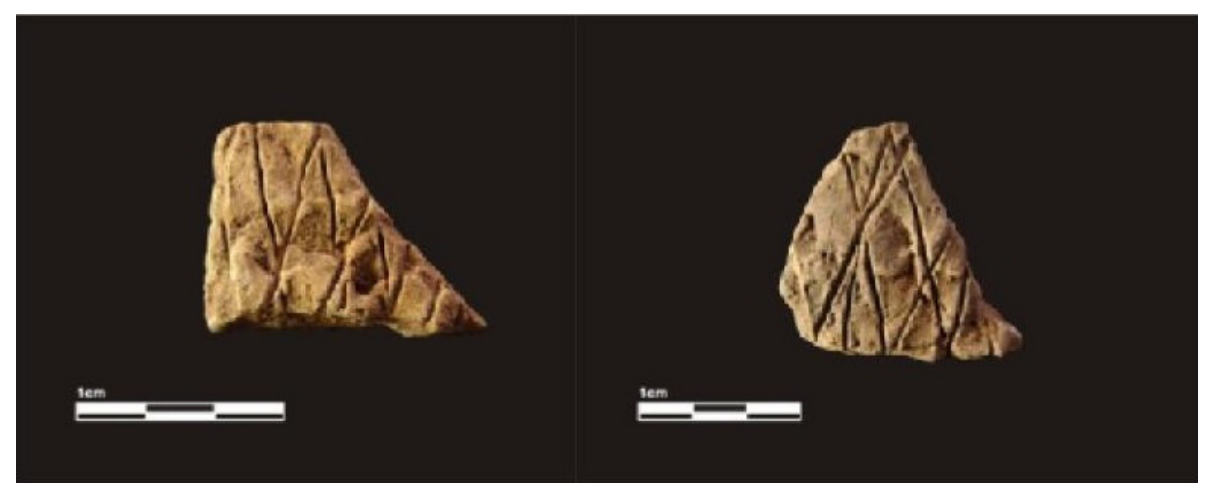

Figura 10 - Fragmentos de paredes com linhas compostas entrecruzadas associadas a motivos plásticos corrugados.

fluvial à margem do rio Guaporé. Este tipo de estrutura é bem frequente na porção do alto-médio rio Guaporé, entre os sítios das fases Corumbiara e Pimenteira (Miller 1983). Sua presença seria um indicativo de momentos de tensão entre as populações pré-coloniais locais, as quais procuravam concentrar suas defesas em aldeias fortificadas com valas ou mesmo paliçadas, visto que os processos de expansão dos grupos Aruak, Caribe e Tupi-Guarani deveriam ocorrer de forma não pacífica (Heckenberger 1996, apud Wüst 2001: 270, 273).

Por outro lado, entre os sítios da cerâmica Córrego Banhado, foi observada a presença de cerâmicas intrusivas pertencentes a outras ocupações ceramistas, sugerindo que períodos de tensões não eram uma constante e que, assim, existiam situações de interdependência tecnológica, necessidade por produtos artesanais ou de matérias-primas comuns aos nichos ecológicos de cada compartimento geomorfológico. Poderiam ser fortes fatores que contribuiriam para o estreitamento de la- ços interétnicos e a criação de redes de trocas organizadas. No sítio Santa Rosa observou-se que um vasilhame associado à indústria da cerâmica Capão do Canga foi depositado como oferenda em uma urna funerária, apresentando, inclusive, duas perfurações para passagem de cordões.

As datações até agora disponíveis indicam que as ocupações relacionadas à cerâmica Córrego Banhado já dominariam a depressão do Guaporé desde 500 AD. É possível que mantivessem seus domínios nos terraços fluviais e nas planícies de baías alto guaporeanas, onde os sítios ainda não são datados. Todavia, é fato que a partir de $800 \mathrm{AD}$ começariam a ceder o espaço da várzea a populações melhores adaptadas ao ambiente alagadiço de pântano, corixos ou paris, com exímio conhecimento de navegação e da extração de recursos deste nicho ecológico, os quais ocasionalmente poderiam vir a necessitar: os povos canoeiros da cerâmica Capão do Canga.

A origem desta ocupação ceramista pode estar associada a migrações do tipo "enxameamento" de povos ca- 
noeiros da bacia do rio Beni/Llanos de Mojos, ou das áreas pantaneiras meridionais da Bolívia, fronteiriças ao Mato Grosso, ou seja, a Província de Santa Cruz de La Sierra. Nos mesmos moldes das Tradições Pantanal (Oliveira 2002, 2004) e Descalvados (Migliacio 2001/2002, 2006), certamente sua economia seria baseada na pesca, caça e coleta, porém, alguma agricultura seria praticada, ou a obtenção de determinados produtos agrícolas poderia ser efetuada por redes de trocas ou mesmo saques em assentamentos de outros grupos ribeirinhos, neste último caso, podemos tomar como exemplo etnohistórico os Payaguá (Smaniotto 2003).

Baseando-se na semelhança do padrão de assentamentos de sítios em terrenos de crostas lateríticas, conforme descrito por Nordenskiöld (2001: 259 e 260) para a área de Mojos, a primeira hipótese de uma contribuição oriunda desta área ou da bacia do Beni pareceria mais plausível, porém, os levantamentos de sítios ao longo do rio Guaporé, não apontam, até o momento, a presença desta cerâmica além de $60 \mathrm{~km}$ ao norte de Vila Bela, embora o sítio
Campina localizado 89,2 km a NW sugira alguma associação, por enquanto de difícil comprovação. Por outro lado, essa cerâmica é conhecida em áreas fronteiriças à Bolívia, em uma direção SW e S, através de uma grande coleção procedente da Baía do Palmarito doada ao museu vilabelense. Uma resposta mais concreta poderia vir de um levantamento de sítios, se existentes, nas terras alagadiças além das margens ocidentais do Rio Barbado, na microrregião de Jauru e na Província de Santa Cruz, permitindo, inclusive, inferir em que sentido as rotas migratórias concernentes à esta indústria cerâmica ocorreram.

É representada exclusivamente por sítios registrados no compartimento geomorfológico da Planície e Pantanal do Alto/Médio Guaporé, com seus sítios inseridos nas seguintes subdivisões: Planícies Amplas (A.1) e Planícies Fluviais Restritas (A. 2), respectivamente representados por terrenos de crostas lateríticas circundadas por áreas sazonalmente alagadiças e, por terraços fluviais. Além dos motivos decorativos já explanados, foi obser-

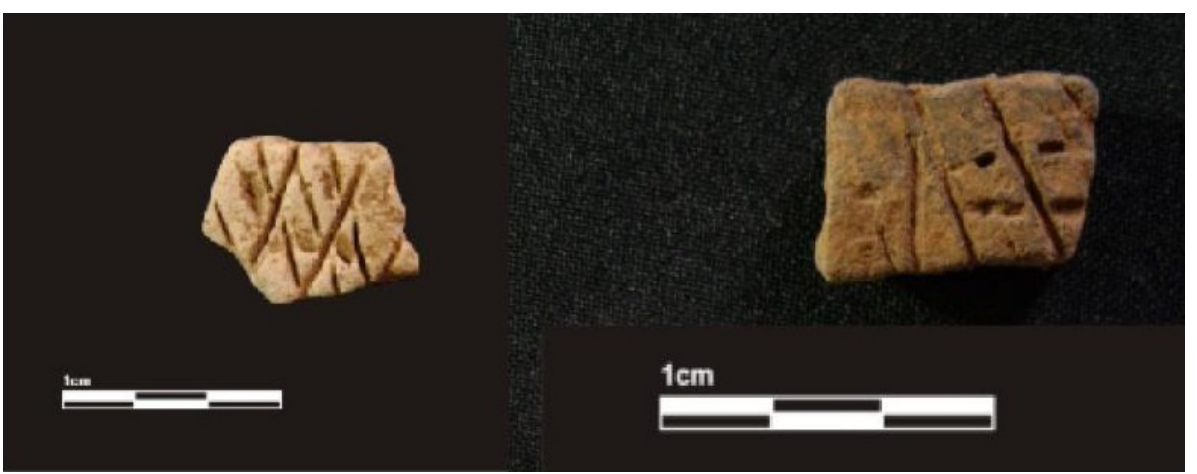

Figura 11 - Linhas compostas entrecruzadas, associadas a acabamento plástico estocado. 


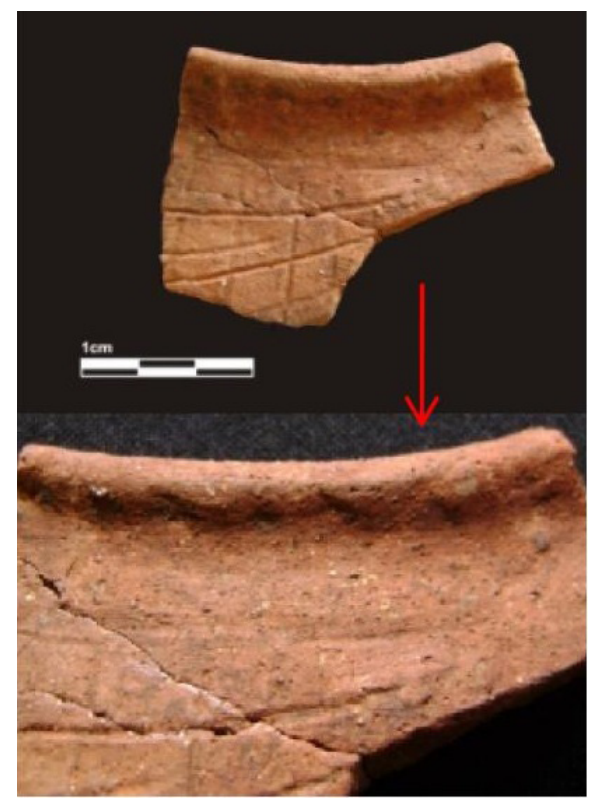

Figura 12 - Fragmento de borda com linhas compostas entrecruzadas associadas a um motivo plástico digitado abaixo do lábio.

vado um detalhe curioso: em alguns exemplos de padrão entrecruzado regular há um único motivo ponteado, cuidadosamente efetuado no centro de um losango ou "escama de peixe", formado pelo cruzamento das incisões: considerando que o resultado de uma escolha técnica/ performance, baseado na experiência e conhecimento pessoal, difere em detalhes entre uma ceramista e outra (Schiffer \& Skibo 1997: 34), é possível que, este motivo ponteado possa ser uma "marca pessoal" de quem produziu o vasilhame, bem como, pode ter sido efetuado no intuito de testar a dureza da argila secada "a frio" antes do utensílio ser submetido à queima (Figura 14).

Enfim, quanto ao padrão de motivos entrecruzados, é possível tecer alguma interpretação? Algumas discussões quanto ao significado desses motivos podem ser efetuadas de modo estimativo a partir de comparação com estudos de grafismos indígenas contemporâneos, bem como através de abordagens arqueológicas, visto que as artes nas sociedades indígenas podem ser entendidas como "um código em um sistema de comunicação intrínseco à cultura" (Schaan 1997: 171).

Hegmon (1992: 525), ao citar o trabalho de David et al. (1988) intitulado "Why pots are decorated", nos explana que as cerâmicas auxiliam no reforço de valores sociais:

"Designs on pottery, far from being "mere decoration", art for art's sake, or messages consciously emblemic of ethnicity, are low-technology channels through which society implants its values in the individual-every day at mealtimes" (David et al. 1988:379.)

Wüst (1990), ao estudar os sítios arqueológicos dos rios Vermelho e São Lourenço, propunha que a variabilidade artefatual existente entre esses poderia representar proto-clãs de grupos Bororos, observações estas também

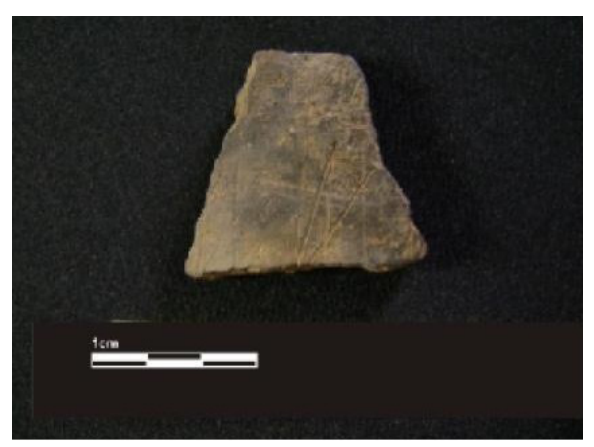

Figura 13 - Linhas compostas entrecruzadas, associadas a um acabamento plástico escovado. 


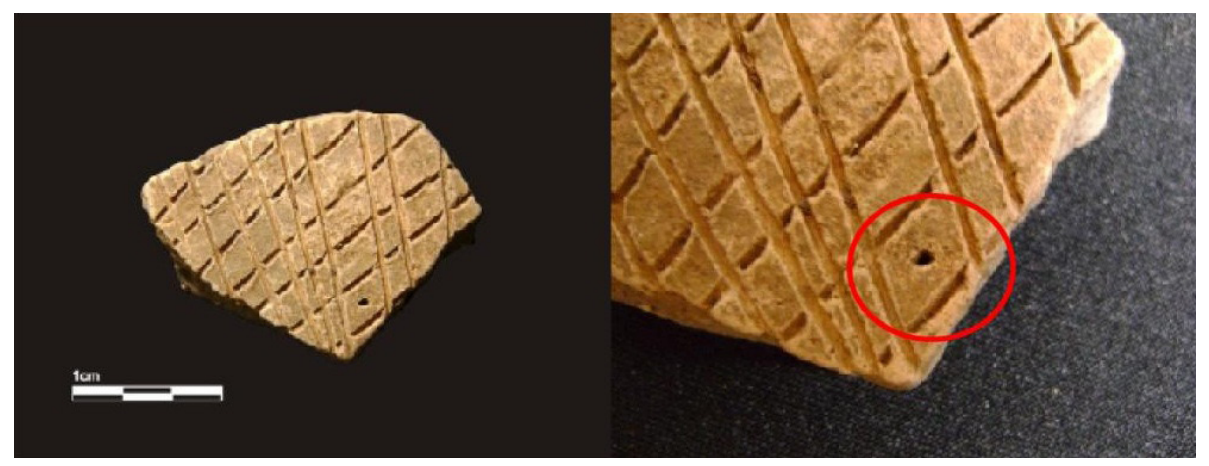

Figura 14 - Exemplo de parede com decoração plástica incisa no motivo de linhas compostas entrecruzadas. Todavia, curiosamente, apresenta como técnica associada, através de alguns exemplos observados, um motivo ponteado, certamente efetuado com auxílio de um espinho de palmeira de tucum (Astrocarium spp.), o qual sempre se encontra em um gomo formado pelo cruzamento das incisões, sugerindo a possibilidade de ser uma espécie de "assinatura" por parte de uma mesma pessoa ao confeccionar vasilhames.

apoiadas por informantes desta etnia quando intencionava localizar suas antigas aldeias. Neste sentido, a variabilidade dos padrões decorativos existentes na cerâmica Capão do Canga poderiam vir a representar divisões clânicas, todavia, esta hipótese deveria ser testada com análises estatísticas tendo como os principais atributos os padrões decorativos supracitados, os quais, até o momento ocorrem mesclados nas coleções analisadas, não predominando até o momento em um ou outro sítio.

Hodder (1981: 94-95) previne que, até mesmo em uma escala intra-aldeia, é preciso discutir variabilidade estilística tomando-se em conta as relações e tensões sociais, além da natureza simbólica da cultura material. Plog (1983: 130) menciona que as análises de D. Newton sobre dois atributos tênues observados no trançado de redes Timbira, apontaram a existência de significantes indicadores estatísticos de limites tribais, como duas entidades tribais distintas, aprendidas apenas por observação e experimentação, de modo não verbal (Ribeiro 1992). Outro exemplo ocorre entre os cesteiros Mundurukú, grupo Tupi do sul do Pará, cujos cestos cargueiros (itiu) apresentam diferenças nos motivos decorativos e nas alças de sustentação, permitindo uma identificação da estrutura da família nuclear, bem como a do clã patrilinear e as metades exogâmicas nesta sociedade indígena, representadas pelas cores brancas e vermelhas (van Velthem 1998: 88-89).

Os estudos efetuados por Müller (1990: 233, 237-239) sobre os padrões básicos dos desenhos Asuriní, grupo Tupi do baixo Xingu apontam a existência de uma nomenclatura para determinados grafismos conforme seja o seu referencial: sobrenatural, elementos de fauna e flora, cultura material (o próprio grafismo e a arte de desenhá-lo). Se considerarmos a hipótese dos grafismos da cerâmica Capão do Canga serem 


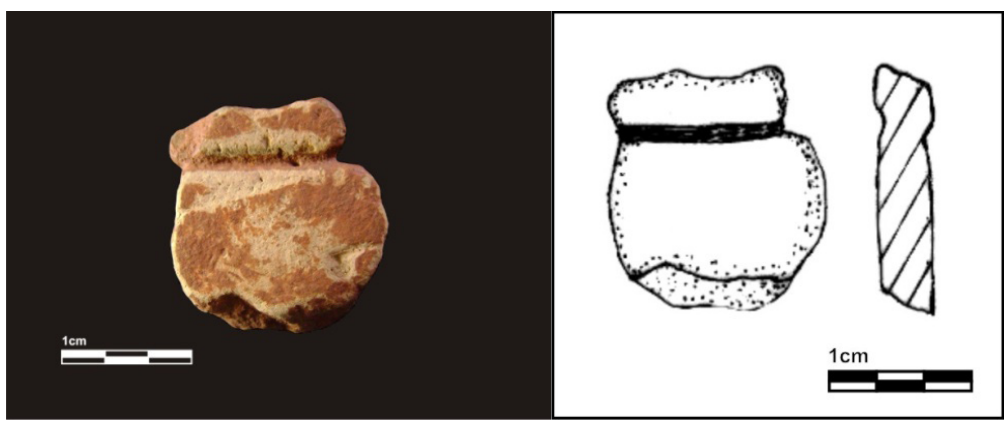

Figura 15 - Artefato cerâmico específico, correspondendo a um provável peso de rede reciclado a partir de um fragmento de vasilhame. Observar o sulco na porção superior para amarração do cordame. Não se descarta também a possibilidade da peça ser de função lúdica.

representações de pinturas corporais, não podemos esquecer o importante papel que essa arte desempenha nas sociedades indígenas, tal como observado por Vidal (1992: 144) entre os Kayapó-Xicrin do sudeste do Pará: um sistema de comunicação visual rigidamente estruturado, relacionado com outros meios de comunicação, verbais ou não.

Uma cerâmica descrita por Monteiro (2005: 66, 77) como não filiada, identificada nos sítios Ferraz Igreja e Caverna do Cipó, apresenta grande semelhança com a cerâmica Capão do Canga, sendo, inclusive, contemporânea a ela, datada de 1300 a 600 AP (700 a 1400 AD aproximadamente).

Em seus sítios não foram reconhecidas, até o momento, estruturas defensivas como valas e amuradas de terra, o que leva a acreditar que, em períodos de instabilidade, o próprio ambiente alagadiço, inerente ao padrão de assentamento de seus sítios, constituiria sua defesa: qualquer incursão belicosa sem o auxílio de embarcações seria impraticável. Em períodos de guerras isto implicaria em deslocamentos e buscas constantes por nichos ecológicos de ambientes pantanosos, os quais, sazonalmente, poderiam a vir se tornar mais secos, dependendo da cota de inundação e proximidade com as grandes drenagens mais estáveis, estação do ano ou mesmo influência de períodos de maior aridez.

\section{AS REDES DE TROCAS NA ÁREA EM ESTUDO}

Conforme já mencionado, a presença intrusiva das cerâmicas das Tradições Uru e Tupiguarani foi observada nos sítios associados às cerâmicas Capão do Canga e Córrego Banhado. Essa situação ocorria também entre as duas últimas, ou pelo menos em uma situação de trade sherds ou cerâmicas trazidas de outros sítios (Ledergeber-Crespo 1995: 369), dentro uma integração entre populações de várzea e zonas de interflúvio.

A partir de $800 \mathrm{AD}$ os povos canoeiros da cerâmica Capão do Canga, com maior conhecimento tecnológico de 
técnicas de navegação e de exploração de recursos de ambientes pantaneiros, passariam a manter maior domínio nos ambientes de várzea do rio Guaporé. Estrategicamente, ao assenhorearemse dos pântanos e dos rios, muitos grupos das áreas de interflúvio passaram a depender ou, em determinadas condições, a se submeter ao seu jugo, visto a necessidade de obtenção de recursos das várzeas, ideia já proposta para sítios de zonas de interflúvio na Amazônia Central (Erig Lima 2003).

Conforme a explicação de Queiroz (2001: 120), na Amazônia oriental os caminhos que permitiram a conquista dos colonizadores nas primeiras décadas do século XVIII eram representados pelos rios que compunham a bacia Amazônica, em oposição ao sistema de estradas utilizadas pelos bandeirantes paulistas pelo interior do Brasil. O quadro não deveria diferir muito nos tempos pré-coloniais, pois os rios eram os corredores de acessos para invasões ou obtenção de recursos e bens de consumo em áreas longínquas; quem os dominasse, em termos estratégicos de territorialidade ou de acesso aos seus recursos, manteria certo controle sobre as demais populações que deles viessem a necessitar. $\mathrm{O}$ alto rio Guaporé não deve ter fugido à regra. Quem comanda o rio e seus recursos, comanda a vida.

Sua cerâmica, principalmente as de decoração pintada (alguns exemplos estudados com singular beleza), certamente seriam produtos cobiçados pelas populações da depressão do Guaporé, conforme pode ser atestado através de alguns fragmentos de bordas associados a vasilhames com função de estocagem, fragmentos decorados incisos ou pintados, obedecendo a um padrão de linhas entrecruzadas (sítios Subestação Galera, Fazenda Conquista e Fazenda Primavera), ou mesmo peças completas associadas a contextos funerários (Sítio Santa Rosa).

Algumas formas descritas para a cerâmica Córrego Banhado assemelham-se às formas da cerâmica Capão do Canga. Isso bem pode indicar a presença de vasilhames alóctones trazidos das planícies de Inundação do alto/médio rio Guaporé, bem como uma situação em que, a partir de um momento, as cerâmicas locais da depressão do Guaporé passam a copiar e reproduzir as formas dos vasilhames da cerâmica Capão do Canga, principalmente no que concerne à forma e função. As similaridades estilísticas em larga escala (intersítio) são umas das maiores fontes potenciais de informação sobre a natureza de interação social entre comunidades préhistóricas (Davis 1983: 83).

Vasilhames cerâmicos têm sido usados para avaliar a interação social de diversas maneiras. A similaridade do design pode indicar tanto a troca de vasilhames como contatos sociais que resultam na adoção de designs similares. Todavia, essas hipóteses poderiam ser avaliadas com análises químicas da argila e do tempero, no intuito de detectar o local de produção de estilos alóctones, enquanto análises regionais de produção e distribuição cerâmica identificariam áreas de produção para tipos específicos (Rautman1993: 415). Wüst (1990: 23) 
ao se referir ao modelo de Hantmann \& Plog (1982), explica que a manutenção de status e de alianças políticas pode ser figurada como símbolos através da permanência ou da alteração de estilos.

Outro exemplo a ser citado é a presença de um vasilhame (forma CG 4) da cerâmica Capão do Canga, descrito no Sítio Santa Rosa (depressão do Guaporé). Esta peça é bem interessante: além do fato de ser um raro exemplar completo, exibia uma pintura monocroma vermelha (motivos de linhas entrecruzadas e de retângulos de intervalos vazios ou cheios), brunidura interna, bem como duas perfurações na borda (efetuadas pós-cozimento) para passagem de cordões. O refinado acabamento pintado dessas peças as faria muito apreciadas, a ponto de servirem de oferendas funerárias, visto o vasilhame descrito ter sido encontrado dentro de uma urna utilizada para este fim, quiçá ocupada por um personagem de destaque em sua sociedade. Conforme apontado por Schortman (1989: 60), à medida que as interações intersociais aumentam, há uma maior interdependência entre as sociedades, especialmente por parte das elites, por bens necessários.

Também é bastante chamativa a similaridade dos padrões de linhas entrecruzadas incisas da cerâmica Capão do Canga, com alguns fragmentos cerâmicos estudados nos sítios Ferraz Igreja e Caverna do Cipó (Monteiro 2005: $66,77)$. Se, futuramente, vier a se comprovar alguma ligação entre a planície de inundação do alto/ médio rio Guaporé com a Serra das Araras, então é possível imaginar que a influência dos povos canoeiros da cerâmica Capão do Canga para o binterland atingiria distâncias muito mais longínquas.

Partindo das ideias de Schortman (1989: 55, 59) de que os processos de interação inter-regional são alavancados por uma questão de identidade social, as cerâmicas decoradas Capão do Canga, principalmente as pintadas, seriam estimadas como símbolos altamente visíveis e reconhecidas por todos os grupos envolvidos em processos de interação, empregadas como sinais de identidade entre seus membros. O uso dessas evidentes afiliações serviria estrategicamente para manter controle através dos limites de identidade, conforme fosse necessário, sobre determinados recursos, trocas, terras, poder político, forças de trabalho, etc., como pode ser atestado pelos sistemas de interação da cultura Hopewell, no nordeste dos EUA, ou entre algumas culturas africanas da África Ocidental, como as dos Swahili e Hauçáa $a^{10}$, cujas redes de trabalho, cooperação e comunicação facilitariam a circulação de mercadorias entre as comunidades.

Estudos desenvolvidos por Uphan et al. (1981: 822-823, 830) demonstraram que assentamentos não igualitários, de variadas organizações e complexidades, teriam se desenvolvido no planalto sudoeste dos EUA por volta de $600 \mathrm{AD}$, onde haveria distribuição diferenciada de trabalho intensivo e mercadorias exóticas, restritos a centros políticos e econômicos. Os padrões de distribuição apontam que algumas famílias empregariam estratégias de reforço 
de influência e status no grupo local, empregando pessoas na produção de excedentes e monopolizando as trocas regionais.

Seja por vias pacíficas ou bélicas, pode ser esse o mecanismo que permitiu haver uma similaridade entre as cerâmicas de grupos pantaneiros do Capão do Canga e as existentes em abrigos da Serra das Araras. $\mathrm{Na}$ medida em que fosse vantajoso aos interesses das populações do interior, adquirir vasilhames, copiar e reproduzir as formas e os motivos decorativos seria um mecanismo de ser afiliado a uma mesma identidade social: "somos da sua gente".

Um curioso fato documentado por Hodder (1982: 43-44) para o distrito do Lago Baringo, Quênia, envolve alguns grupos étnicos locais (Kokwa, Karau, Njemp, Pokot, Tugem), cujas mulheres se dedicavam à atividade ceramista. Uma ceramista Karau, ao vender seus vasilhames aos Njemp teve de confeccioná-los à moda deste grupo étnico: "Apropriar-se de um tipo de pote Njemp é parte e parcela da essência Njemp". Por outro lado, entre os Kokwa, o ato de terem suas cerâmicas copiadas pelos Karau não parecia ser bem visto.

Pauketat e Emerson (1991) demonstraram que determinados vasilhames da cultura Cahokia (séculos XI e XII), Vale do Mississipi, EUA, serviriam como veículos simbólicos ativos de ordem, hierarquia e religiosidade dentro dos discursos de legitimação das principais autoridades locais. Essas elites teriam o papel de mediadores entre o cosmos e os demais membros da população não afiliados à elite.
Em contrapartida, as populações da depressão do Guaporé poderiam ser as principais intermediárias entre os grupos Gê da Chapada dos Parecis e os grupos das várzeas do Guaporé, principalmente pela adoção de utensílios característicos da Tradição Uru, empregados no preparo de alimentos à base mandioca e milho, no caso as assadeiras de beijú e os cuscuzeiros. Um pormenor interessante é que os grandes assadores no Planalto Central parecem ter surgido a partir do século XII, de acordo com os sítios Uru estudados no rio Vermelho, sudeste do Mato Grosso (Wüst 1990, 1992: 19).

Utensílios e tecnologia de produção cerâmica Uru passaram a ser bem aceitos pelos canoeiros da cerâmica Capão do Canga, ao julgar pela presença de assadeiras (indicando também a adoção do cultígeno da mandioca em pequena escala) e de cariapé no tempero de suas cerâmicas.

Outro ponto a chamar a atenção é a origem dos pesos de fusos estrelados e as armações de maças líticas (itaiçás) com forma estrelada ou circular, registrada na depressão do Guaporé.

A primeira hipótese é que o conhecimento tecnológico de confecção artesanal desses artefatos há mais tempo teria sido transmitido de áreas andinas/subandinas para as populações das tierras bajas da Bolívia, no caso das itaiçás. Essas populações englobariam as culturas de Los Mojos e as da bacia do rio Beni; que, por sua vez, teriam desenvolvido o peso de fuso estrelado. Considerando as ligações entre Los Mojos (culto do Jaguar), o Complexo 
de Los Gomales e as culturas cerâmicas do médio rio Guaporé (fases Pimenteira e Corumbiara), essas peças passariam a ser adotadas em uma continuidade de produção no contexto cultural dessas. O sentido simbólico de circulação dessas itaiçás ${ }^{11}$ não muito diferiria das redes de trocas envolvendo os pingentes de pedras verdes ou "muiraquitãs", através do norte da América do Sul e as Índias Ocidentais (Boomert 1987), ou, como em outros exemplos etnográficos observados: o Kula, praticado entre as Ilhas Trobriand e arquipélagos vizinhos na Melanésia, onde determinados objetos dotados de valor simbólico circulavam de uma ilha a outra, como um valor de moeda, entre os quais as bagi e as soulava (colares e braceletes de contas de conchas polidas), os kukumali (percutores de diorito utilizados para lascar as conchas na confecção de contas, cujos afloramentos não existem nas Trobriand), além das beku, grandes lâminas de machado polido de rocha esverdeada (Malinowski 1978).

Diante do espectro de troca de elementos de produção cerâmica e os produtos deles derivados, não podemos esquecer o exemplo estudado por Wüst (1990, 1992: 19, 21) para a área do rio Vermelho (afluente do São Lourenço) onde entre 63 sítios, 34 estavam associados à Tradição Uru, 23 a antigos assentamentos Bororos e seis a Subtradição Pintada Tupiguarani. Entre esses últimos, o material cerâmico apresentava fortes influências da Tradição Uru; um pequeno porcentual de cerâmica atribuída aos Bororo, com certa influência da tradição Tupiguarani e vice-versa.

Enfim, a partir dos exemplos discutidos acima, não nos restam dúvidas que uma situação de interdependência tecnológica e as consequentes redes de trocas por ela geradas influenciaram períodos de integração ou de conflito interétnico entre as populações pré-coloniais da área em estudo, porém, como este processo teria se desenvolvido?

Possivelmente este fluxo constante de lâminas de machados, itaiçás, utensílios cerâmicos e demais bens artesanais, dentro das redes de interdependência tecnológica e redes de comércio estudadas na área, poderia ser estimulado pelas migrações de retorno, conforme postulado pelo modelo de migração de Anthony (1990: 904), onde "batedores" e "exploradores" eram os mensageiros de bens curiosos e atraentes, oriundos de lugares tão distantes, até que as redes de informações e trocas fossem definitivamente estabelecidas.

As sociedades não são entidades isoladas e autossuficientes, mas antes se inserem em uma ampla variedade de interações que resultam em interdependências muito difundidas. Quando duas populações se beneficiam mutuamente ao dividirem recursos, principalmente alimentícios, dois modelos ecológicos operam em matéria de aquisição desses recursos inter-sociais: resguardo (buffering), onde a falta localizada de alimentos é aliviada pelo acesso às fontes disponíveis em outros territórios, exigindo o deslocamento de populações para territórios que contenham os recursos de que necessitem; e mutualismo, onde as relações são baseadas em trocas, criando-se uma dependência que pode 
ser explorada se as diferenças de poder expandem-se entre as sociedades, ou se as relações de trocas são manobradas (Spielmann 1986: 281, 288).

Rogge (2004: 153), ao estudar fenômenos de fronteira ${ }^{12}$, no Rio Grande do Sul, explica que ao final do primeiro milênio da Era Cristã, a tradição Tupiguarani, em um processo de colonização e expansão, teria ocupado as áreas de Floresta Estacional, tornandose marcante em muitos locais o contato com as tradições Taquara e Vieira, levando à elaboração de estratégias de exploração e controle territorial, a conflitos (segundo fontes etnohistóricas) ou a integrações (segundo dados arqueológicos) entre essas populações:

“(...) em determinados locais, podem ter gerado situações que envolveram formas integrativas de contato através de processos de interação marcados pelo fluxo de indivíduos, de objetos e/ou elementos estilísticos cerâmicos e pelo intercâmbio econômico" (Rogge 2004: 153).

Ribeiro (1992: 129-130, 135-137) nos oferece interessantes exemplos etnográficos sobre sistemas de interdependência regional e de redes de trocas, cujas informações têm a contribuir com interpretações arqueológicas. Ao abordar o Sistema de Interdependência Regional do Orinoco, estudado por Arvelo-Jimenez et al. (1987, apud Ribeiro 1992), explica que a pluralidade de biótopos (savana, rio, floresta) tendem a distribuir de forma desigual, porém equilibrada, as matérias-primas (afloramentos rochosos, barreiros, cipoais, etc.) a eles associadas. Visto que o fator de portabilidade é limitado, as populações tenderiam a ser dispersas, desprovidas de centralização política, com a produção de modestos excedentes, impossibilitadas de defenderem belicamente seus recursos naturais e culturais. Assim, criavam-se alianças políticas com outras sociedades de estrutura similar, porém sem perda de autonomia política local, cultural ou lingüística, sendo o comércio operado na forma de uma estratégia de interação interétnica, o qual alcançaria distâncias mais longínquas, como os Llanos da Colômbia e Venezuela, circulando não apenas mercadorias, mas também informações.

\section{CONCLUSÕES FINAIS}

É possível que um grande aumento populacional ocasionado por uma migração demográfica, segundo modelo proposto por Anthony (1990: 905), teria se originado a partir do oriente boliviano (província de Mojos/bacias do rio Beni e do rio Mamoré) e do médio rio Guaporé, passando a ocupar a região em estudo por um período de 900 anos, culminando com a primeira grande ocupação ceramista: a cerâmica Córrego Banhado. Tal mecanismo teria se beneficiado por maior oferta de recursos de flora e fauna, bem como não foge ao modelo proposto por Heckenberger (2002) concernente a uma diáspora Aruak.

Posteriormente, a partir de 800 AD, as populações associadas à cerâmica Córrego Banhado cederiam espaço a uma nova ocupação ceramista, desta vez representada por povos canoeiros, 
a qual manterá hegemonia nos ambientes de várzea do Guaporé, representada pela cerâmica Capão do Canga (800-1300 AD), com maior domínio tecnológico de navegação e exploração de recursos em vias fluviais e pantaneiras, essas novas populações se tornaram mais aptas a dominar esses ambientes. Neste período seriam construídas as valas defensivas (tal como um exemplo existente no sítio Fazenda Conquista) munidas de paliçadas, enquanto os canoeiros procurarão se aquartelar em terrenos de crostas lateríticas, sazonalmente cercados por áreas alagadiças, valendo-se da inacessibilidade dos ambientes pantanosos. Sua conquista pelos assentamentos de planícies de baías e terraços fluviais, à moda dos Payaguá etnohistóricos, alguns séculos mais tarde, certamente envolveria ataques constantes e repentinos com apoio de um grande número de guerreiros e canoas, gerando pânico às populações ribeirinhas, que logo abandonariam os assentamentos fluviais guaporeanas e se direcionariam às zonas de interflúvios, concentrando-se em múltiplas aldeias nas cabeceiras do Córrego Banhado e demais afluentes do rio Guaporé, passando a ter um maior domínio pelo compartimento geomorfológico da depressão do Guaporé, a salvo, sobretudo, de ataques de canoeiros, visto a rede fluvial neste compartimento não ser favorável à navegação.

Mais tarde, este período de guerras seria suplantando por tempos de interdependência tecnológica, cooperação mútua quanto à obtenção de produtos de ambientes de várzea versus inter- flúvio, e a consequente formação de redes de trocas, cujas ramificações atingiriam áreas além da bacia do alto rio Guaporé. Porém cada uma dessas duas ocupações ceramistas procuraria controlar os seus domínios geomorfológicos por processos de territorialidade. Certamente os canoeiros da cerâmica Capão do Canga, para frustração dos ceramistas da Depressão do Guaporé, passaram a ter controle pelo recurso estratégico mais cobiçado da região: a calha fluvial do Guaporé em si, a porta e corredor principal de acesso para o que era concebido como mundo na mente desses povos pré-coloniais, e de tudo o que ele tinha a oferecer, não apenas recursos nutritivos, mas bens artesanais estimados e dotados de simbologia de poder vindos de "mundos mais distantes e exóticos", cujo acesso agora dependeria de tributos e negociações com os novos senhores do rio.

A despeito de uma provável belicosidade dos grupos canoeiros da cerâmica Capão do Canga, concentrados no compartimento geomorfológico da planície de inundação do alto/médio rio Guaporé, a sua cerâmica monocroma vermelha seria um dos principais itens prestigiados pelas populações da Depressão do Guaporé, inclusive fazendo parte de oferendas funerárias de seus entes falecidos, talvez dotados de algum status social. Alguns recipientes grandes destinados à armazenagem presentes na tralha doméstica da cerâmica Capão do Canga parecem ter sido enviados à Depressão do Guaporé, sendo posteriormente copiados e reproduzidos quanto à sua forma pelas 
populações das cabeceiras do Córrego Banhado no intuito de suprir a demanda entre os habitantes.

É possível que tenha existido um controle das redes de troca por parte de alguns membros detentores de algum status social: caciques, sibs locais ou mesmo uma classe de caçadores e guerreiros, os quais seriam os "importadores e negociantes”, responsáveis pela organização das expedições de trocas. Assim, a obtenção de um utensílio ou objeto "exótico" dotado de prestígio oriundo dos povos da várzea poderia implicar em uma troca de serviços ou de tributos alimentícios, às vezes não vantajosos para a parte do "comprador", o qual se contentaria com um vasilhame reproduzido mais econômico de adquirir, driblando uma provável contração de dívida por parte de uma elite local.

Em contrapartida, por sua proximidade com a borda da Chapada dos Parecis, as populações produtoras da cerâmica Córrego Banhado obteriam produtos do Cerrado e bens artesanais das populações Tupiguarani e Uru, sendo inclusive influenciadas por esses últimos no que tange à adoção de tecnologia cerâmica: o uso de assadores de beijú e cuscuzeiros, bem como de vasilhames geminados (evidenciado por uma conexão de vasilhame). Bens artesanais, ideias e modos de fazer do Brasil Central, por intermédio das populações da Depressão do Guaporé, chegaram aos grupos Capão do Canga na várzea guaporeana: a partir de um momento alguns de seus vasilhames irão adotar o tempero de cariapé, traço típico da cerâmica Uru, bem como o uso das as- sadeiras de beiju. A cerâmica Tupiguarani teria alcançado os canoeiros como bens de trocas, mas quem sabe influenciado sua cerâmica em alguns aspectos, a julgar pela presença de engobo creme ou de raras paredes corrugadas com decoração incisa sobreposta na forma de linhas entrecruzadas; alguns exemplos de fragmentos cerâmicos com engobo branco se associavam às ocupações da cerâmica Córrego Banhado, quando ainda mantinham algum domínio na várzea. É importante também lembrar que essas cerâmicas atribuídas à Tradição Tupiguarani podem ter alguma correlação com populações indígenas deslocadas da região de Assunção, por expedições espanholas em direção ao Chaco, ou do Itatin pelos mamelucos paulistas.

Ainda dentro do Modelo de Migração de Anthony (1990: 904), o mecanismo da migração de retorno poderia ser um dos fatores dessas peças circularem por distâncias inesperadas; outro exemplo também curioso é a presença de um artefato polido em uma plaqueta de hematita com formato de serra recolhido no sítio Campina, cujo estilo é bastante semelhante às serras líticas da cultura Tapajônica (Palmatary 1960: 229). Esse circuito de circulação de peças "exóticas" é mencionado inclusive em fontes etnohistóricas, como, por exemplo, entre os Chané-Arawak, descritos como "troquistas viajantes", os quais seriam apontados como distribuidores de metais incaicos (Migliacio 2006: 66).

Finalmente, o fechamento do painel arqueológico da microrregião do alto rio Guaporé, bem como de outras 
áreas da bacia Amazônica, ainda será uma tarefa para gerações de pesquisadores, ou seja, pesquisas arqueológicas de caráter exploratório ainda em muito contribuirão na descoberta e reconstrução de seus cenários pré-coloniais ainda desconhecidos ao longo das próximas décadas.

O conteúdo abordado durante a pesquisa de doutorado (Erig Lima 2011) não teve por objetivo esgotar o tema, mas permitiu avaliar os processos de ocupação humana que, possivelmente foram condicionados de acordo com os compartimentos geomorfológicos da região e, no "desenrolar do novelo", foi possível também reconhecer uma indústria ceramista inédita, bem como a existência de fenômenos de territorialidade e de interessantes redes de trocas dentro de uma área chave para o entendimento de processos de interação entre os diversos grupos précoloniais e etnohistóricos do Norte e Centro-Oeste brasileiro e, do território tropical boliviano.

\section{AGRADECIMENTOS}

O presente artigo é um resumo dos resultados alcançados com a tese de doutorado intitulada "A ocupação pré-colonial na fronteira ocidental-adaptabilidade humana, territorialidade e aspectos geomorfológicos na microrregião do alto Guaporé, Mato Grosso", desenvolvida entre 2006 e 2010, sob a orientação da Dra. Marisa Coutinho Afonso $(\mathrm{Mu}-$ seu de Arqueologia e Etnologia da Universidade de São Paulo-MAE/USP) e o apoio da Coordenação de Aperfeiçoamento de Pessoal de Nivel Superior (CAPES). O Projeto Fronteira Ocidental vem sendo desenvolvido sob a coordenação geral do arqueólogo Dr. Paulo Eduardo Zanettini, com verbas da Lei de Incentivo à Cultura do Mato Grosso, constituindo um dos projetos prioritários da Secretaria de Estado de Cultura do MT. A essas instituições e pessoas, meus agradecimentos.

\section{NOTAS}

${ }^{1}$ As datações por TL do sítio Capão do Canga só estiveram disponíveis a partir da data de 18 de Fevereiro de 2010, sendo estas efetuadas pelos Drs. Márcio Yee e Sandra Tatumi, conferindo, de um modo geral, um horizonte cronológico de 800$1300 \mathrm{AD}$.

${ }^{2}$ Os Saraveka eram um dos grupos indígenas que faziam parte do imenso mosaico de povos genericamente chamados de "Chiquitos" pelos espanhóis, gerando também o nome do território "Província de Chiquitos" (Migliaccio 2001/2002: 227).

\section{${ }^{3}$ CNSA-IPHAN.}

${ }^{4}$ Segundo informações prestadas em março de 2009 pelo Sr. Elizeo Ferreira de Souza, antigo Tesoureiro da Prefeitura de Vila Bela, a área de Fazenda Lagoa do Encanto teria abrigado uma pequena comunidade rural negra, outro tema a ser futuramente estudado na área pelo Projeto Fronteira Ocidental.

${ }^{5}$ Fragmentos cerâmicos associados a sedimentos.

${ }^{6}$ Ocasionadas pelo contato direto do vasilhame com o solo ou uma superfície irregular durante sua confecção.

7 Apresentam o prefixo "CG" para especificar a cerâmica Capão do Canga.

${ }^{8}$ Utiliza-se aqui o termo "reciclado" de acordo com a proposição de Schiffer (1972).

${ }^{9}$ Miller (1983) considerou a presença de incisões e motivos ponteados como um indicativo de ambas fases serem inseridas na 
Tradição Inciso-Ponteada.

${ }^{10}$ Enclaves étnicos Hauçá existiriam entre as comunidades Yoruba, através de diáspora de trocas (trade diaspora), conceito desenvolvido por Ronald Cohen para especificar redes inter-regionais compostas de grupos especializados em trocas, culturalmente distintos, independentes de suas comunidades anfitriãs, porém mantinham altos níveis de laços econômicos e sociais com comunidades que se auto definiam como de mesma identidade cultural (Stein 2002: 908).

${ }^{11}$ Pessoalmente tive a oportunidade de observar esses artefatos em coleções particulares de garimpeiros na cidade de Pimenta Bueno, Rondônia, por volta de 1996. Essas peças são retiradas por consequência da garimpagem de diamantes nos rios Ji-Paraná (ou Machado), Apediá (ou Pimenta Bueno), Comemoração (ou Barão de Melgaço), sendo encontradas grandes quantidades de lâminas de machado, peças cerâmicas e outros artefatos. $\mathrm{O}$ fato é que as itaiçás, ou modo de confeccioná-las, foram além do vale do Guaporé, alcançando não apenas o estado de Rondônia, mas o cone sul americano.

${ }^{12}$ Segundo Rogge (2004: 149), entende-se por "zonas de fronteira" espaços geográficos definidos, onde ocorrem marcadores relativamente eficientes, como relações entre assentamentos arqueológicos e seus conhecidos estilos cerâmicos.

\section{REFERÊNCIAS}

Anthony, D. W. 1990. Migration in archaeology: the baby and the bathwater. American Anthropologist 92(4): 895-914.

Boomert, A. 1987. Gifts of the Amazons: "green stone" pendants and beads as items of ceremonial exchange in Amazonia and the Caribbean. Antropológica 67:33-54.
David, N., J. Sterner, K. Gavua. 1988. Why pots are decorated. Current Anthropology Chicago, 29:365-89.

Davis, D. D. 1983. Investigating the diffusion of stylistic innovations, in Advances in Archaeological Method and Theory vol. 6. Editado por M. Schiffer, pp. 53-89. New York: Academic Press.

Erig Lima, L. F. 2003. Levantamento arqueológico das áreas de interfluivio na área de confluência dos rios Negro e Solimões. Dissertação de Mestrado. Museu de Arqueologia e Etnologia da Universidade de São Paulo, São Paulo, Brasil.

.2005. Arqueologia pré-colonial do município de Vila Bela da Santíssima Trindade/ MT, in XIII Congresso da Sociedade de Arqueologia Brasileira. Arqueologia, patrimônio e turismo [CDROM]. Campo Grande: Editora Oeste.

2007. A Depressão do Guaporé: uma abordagem arqueológica no âmbito do ramal de distribuição rural $34,5 \mathrm{Kv}$, Conquista d'Oeste, MT, in XIV Congresso da Sociedade de Arqueologia Brasileira. Arqueologia, etnicidade e território [CD-ROM], Florianópolis: SAB.

.2009. Levantamento de sítios rupestres e de abrigo sob rocha no município de Nova Lacerda, Depressão do Guaporé - MT. Revista do Musen de Arqueologia e Etnologia 8: 111-119.

2011. A Ocupação pré-colonial na fronteira ocidental: Adaptabilidade bumana, territorialidade e aspectos geomorfológicos na microrregião do alto Guaporé, Mato Grosso. Tese de Doutorado. Museu de Arqueologia e Etnologia da Universidade de São Paulo, São Paulo, Brasil.

Fogaça, E. \& D.R. Sampaio. 2003. O material lítico do sítio Guapé 14 (alto Guaporé, Mato Grosso, Brasil): uma análise tecnoergonômica dos instrumentos líticos, in XII Congresso da Sociedade de Arqueologia Brasileira. Arqueologias da América Latina [CD-ROM]. São Paulo: SAB.

Hantmann, J. L. \& S. Plog. 1982. The re- 
lationship of similarity to the patterns of material exchange, in Contexts for prehistoric exchange. Editado por E. Ericson \& T.K. Earle, pp. 237-263. New York: Academic Press.

Heckenberger, M. J. 2002. Rethinking the Arawakan diaspora: Hierarchy, regionality, and the Amazonian formative, in Comparative Arawakan histories. Editado por J. D. Hill \& F. Santos Granero, pp. 99-122. Urbana: University of Illinois.

Hegmon, M. 1992. Archaeological research on style. Annual Review of Anthropology 21: 517-536.

Hodder, I. 1981. Society, economy and culture: an ethnographic case study amongst the Lozi, in Pattern of the past: studies in honor of David Clarke. Editado por I. Hodder, G. Isaac \& N. Hammond, pp. 67-95. Cambridge: Cambridge University.

1982. Symbols in action: Ethnoarcheological studies of material culture. Cambridge: Cambridge University.

Malinowski, B. K. 1978. Argonautas do Pacifico ocidental: um relato do empreendimento e da aventura dos nativos nos arquipélagos da Nova Guiné, Melanésia. São Paulo: Abril Cultural.

Meireles, D. M. 1989. Guardiões da fronteira: Rio Guaporé, século XV III. Petrópolis: Vozes.

Métraux, A. 1948. Tribes of Eastern Bolivia and the Madeira headwaters, in Handbook of South American Indians, v. 3: The tropical forest tribes. Bulletin, n. 143. Editado por J. Steward, pp. 381-463. Washington: Smithsonian Institution Bureau of American Ethnology.

Migliacio, M. C. 2001/2002. A ocupação indígena do Pantanal de Cáceres, Alto Paraguai, do período pré-colonial aos dias atuais. Revista do Museu de Antropologia 5/6 (1): 213-250.

2006. O doméstico e o ritual: o cotidiano Xaray no Alto Paraguai até o século XVI. Tese de Doutorado. Museu de Arqueologia e Etnologia da Universidade de São Paulo, São Paulo, Brasil.

Miller, E. Th. 1983. História da cultura indígena do Alto Médio-Guaporé (Rondônia e Mato Grosso). Dissertação de Mestrado. Pontifícia Universidade Católica do Rio Grande do Sul, Porto Alegre, Brasil.

1987. Pesquisas arqueológicas paleoindígenas no Brasil ocidental. Estudios Atacameños 8: 37-61.

2000. A limitação ambiental como barreira à transposição do período formativo do Brasil: Tecnologia, produção de alimentos e formação de aldeias no sudoeste da Amazônia, in Formativo sudamericano: una revaluación. Editado por P. LedergerberCrespo, pp.331-351. Quito: Abya-Yala.

Moi, F. P., E. R. Souza, W. F. Morales \& R. W. A. Paresi. 2009. Memória e oralidade: interpretação de grafismos rupestres entre os Aruak do noroeste do estado do Mato Grosso, Brasil, in Cenários regionais em arqueologia brasileira. Organizado por W. F. Morales \& F. P. Moi, pp.205-237. São Paulo: Annablume; Porto Seguro: Acervo Centro de Referência em Patrimônio e Pesquisa.

Monteiro, L. C. 2005. Abrigos e aldeias: Análise dos contextos tecnológicos das ocupações de ceramistas na Cidade de Pedra, Rondonópolis, Mato Grosso. Dissertação de Mestrado. Museu de Arqueologia e Etnologia da Universidade de São Paulo, São Paulo, Brasil.

Morais, J. L. 2000. Tópicos de arqueologia da paisagem. Revista do Museu de Arqueologia e Etnologia 10:3-30.

Müller, R. P. 1990. Os Asurini do Xingu: História e arte. Campinas: Unicamp.

Nordenskiöld, E. 2001. Exploraciones y aventuras en Sudamerica. La Paz: Apoyo para el Campesino Indígena del Oriente Boliviano (APCOB).

Oliveira, J. E. 2002. Da pré-bistória à história 
indigena: (re) pensando a arqueologia e os povos canoeiros do Pantanal. Tese de Doutorado. Instituto de Filosofia e Ciências Humanas da Pontifícia Universidade Católica do Rio Grande do Sul, Porto Alegre, Brasil. 2004. Arqueologia das sociedades indígenas do Pantanal. Campo Grande: Editora Oeste.

Palmatary, H. C. 1960. The archaeology of the Lower Tapajós Valley, Brazil. Transactions of the American Philosopbical Society 50(3): 1-243.

Pauketat, T. R. \& T. E. Emerson. 1991. The ideology of authority and the power of the pot. American Antbropologist 93(4): 919-941.

Plog, S. Analysis of style in artifacts. 1983. Annual Review of Anthropology 12: 125-42.

Puttkamer, W. J. V. 1979. Brazil's ancient shelter of the sun. National Geographic 155(1): 72-84.

Queiroz, J. M. 2001. Anotações às margens da história: Quilombolas e republicanos nas origens do Amapá, in Amazônia: modernização e conflito (séculos XVIII e XIX). Organizado por J. M. Queiroz \& M. C. Coelho, pp. 117-155. Belém: Universidade Federal do Pará: NAEA.

Rautman, A. E. 1993. Resource variability, risk, and the structure of social networks: Aan example from the prehistoric Southwest. American Antiquity 58(3): 403-424.

Ribeiro, B. G. 1992. Perspectivas etnológicas (1957-1988) para arqueólogos, in Prehistoria sudamericana: Nuevas perspectivas. Editado por B. J. Meggers, pp. 113-142. Washington: Taraxacum.

Rogge, J. H. 2004. Fenômenos de fronteira: o contato cultural entre os portadores das tradições cerâmicas pré-históricas no Rio Grande do Sul. Canindé: Revista do Museu de Arqueologia de Xingó 4:147-168.

Schaan, D. P. 1997. A linguagem iconográfica da cerâmica marajoara: um estudo da arte pré- bistórica na Ilha de Marajó, Brasil (400-1300 $A D)$. Porto Alegre: EDIPUCRS.

Schiffer, M. B. 1972. Archaeological context and systemic context. American Antiquity 37(2): 156-165.

Schiffer, M. B. \& J. M. Skibo. 1997. The explanation of artifact variability. American Antiquity 62(1):27-50.

Schortman, E. M. 1989. Interregional interaction in prehistory: the need for a new perspective. American Antiquity 54(1): 52-65.

Skibo, J. M., M. B. Schiffer \& K. C. Reid. 1989. Organic-tempered pottery: an experimental study. American Antiquity 54(1): 122-146.

Smaniotto, E. 2003. Relações de gênero entre populações indígenas nômades do chaco: Abipón, mocovi, toba, payaguá e mbayá, séc. XVIII. Dissertação de Mestrado. Universidade do Vale do Rio dos Sinos, São Leopoldo/RS, Brasil.

SPVS-Sociedade de Pesquisa em Vida Selvagem e Educação Ambiental. 1997a. Estudo ecológico rápido para a criação e implantação da unidade de conservação da Serra de Santa Bárbara. Cuiabá: Governo do Estado do Mato Grosso, Programa de Desenvolvimento Agroambiental (PRODEAGRO), Fundação Estadual do Meio Ambiente (FEMA MT), Coordenadoria de Pesquisa e Planejamento Ambiental, Divisão de Unidades de Conservação, pp. 81-90.

.1997b. Estudo ecológico rápido para a criação e implantação da unidade de conservacãa da Serra de Ricardo Franco. Cuiabá: Governo do Estado do Mato Grosso, Programa de Desenvolvimento Agroambiental (PRODEAGRO): Fundação Estadual do Meio Ambiente (FEMA MT), Coordenadoria de Pesquisa e Planejamento Ambiental, Divisão de Unidades de Conservação, pp. 85-96.

Spielmann, K. A. 1986. Interdependence among egalitarian societies. Journal of $A n$ thropological Archaeology 5(4): 279-312. 
Stein, G. J. 2002. From passive periphery to active agents: emerging perspectives in the archaeology of interregional interaction. American Anthropologist 104(3): 903-916.

Uphan, S., K.G. Lightfoot \& G. M. Feinman. 1981. Explaining socially determined ceramic distributions in the prehistoric Plateau Southwest. American Antiquity 46(4): 822-833.

Van Velthem, L. H. 1998. Arte indigena: referentes sociais e cosmológicos, in Índios no Brasil. Editado por L. D. Grupioni, pp. 83-92. São Paulo: Global.

Vidal, L. A. 1992. Pintura corporal e a arte gráfica entre os Kayapó-Xikerin do Cateté, in Grafismo indígena. Organizado por L. A. Vidal, pp. 143-189. São Paulo: EDUSP: Studio Nobel.

Wüst, I. 1990. Continuidade e mudança: Para uma interpretação dos grupos ceramistas pré-coloniais da bacia do Rio Vermelho, Mato Grosso. Tese de Doutorado. Faculdade de Filosofia, Letras e Ciências Humanas da Universidade de São Paulo, São Paulo, Brasil.

1992. Contribuições arqueológicas, etnoarqueológicas e etnohistóricas para o estudo dos grupos tribais do Brasil Central: o caso Bororo. Revista do Museu de Arqueologia e Etnologia 2: 13-26.

2001. Resgate dos sitios arqueológicos Guapé 1 e 2 na área das obras construtivas da UHE-Guaporé, MT. Primeira etapa. Relatório Final. Vol. 1. Goiânia: Grupo Rede Tangará.

Zanettini Arqueologia. 2002. Diagnóstico arqueológico de trecho circunscrito no contorno do municipio de Vila Bela e ponte sobre o Rio Guaporé, jazidas (J-1) e áreas de empréstimo: Vila Bela da SS. Trindade, MT. São Paulo, inédito.

2004a. Projeto fronteira ocidental arqueologia e história: Vila Bela da Santíssima Trindade, fase 2. São Paulo: SECMT.

2004b. Projeto São Francisco: programa de prospecções, resgate e monitoramento arque- ológico, Vila Bela da Santíssima Trindade, Mato Grosso. Relatório final. São Paulo, inédito. . 2006. Projeto São Francisco: programa de prospecções e monitoramento arqueológico, ramal de distribuicão rural de 34,5 kV, trecho P0-P1 - Mina de São Francisco; retificação do traçado, Vila Bela da Santíssima Trindade, Mato Grosso. Relatório final. São Paulo, inédito.

. 2007. Projeto São Francisco: programa de prospecções e monitoramento arqueológico, ramal de distribuição rural de 34,5 kV, trecho P0-P1

- Mina de São Francisco; retificação do traçado, Vila Bela da Santíssima Trindade, Mato Grosso. Relatório final. São Paulo, inédito.

Recebido em 05/02/2012.

Aprovado em 07/03/2012. 